\title{
Production of microalgae with high lipid content and their potential as sources of nutraceuticals
}

\author{
Aswathy Udayan - Ashutosh Kumar Pandey - Ranjna Sirohi • \\ Nidhin Sreekumar • Byoung-In Sang • Sung Jun Sim • Sang Hyoun Kim • \\ Ashok Pandey (D)
}

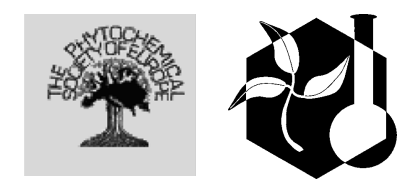

Received: 16 July 2021 / Accepted: 7 October 2021

(C) The Author(s), under exclusive licence to Springer Nature B.V. 2021

\begin{abstract}
In the current global scenario, the world is under a serious dilemma due to the increasing human population, industrialization, and urbanization. The ever-increasing need for fuels and increasing nutritional problems have made a serious concern on the demand for nutrients and renewable and eco-friendly fuel sources. Currently, the use of fossil fuels is creating ecological and economic problems. Microalgae have been considered as a promising candidate for high-value metabolites and alternative renewable energy sources. Microalgae offer several advantages such as rapid growth rate, efficient land utilization, carbon dioxide sequestration, ability to cultivate in
\end{abstract}

Aswathy Udayan, Ashutosh Kumar Pandey and Ranjna Sirohi have contributed equally to this work and shared co-first authorship.

A. Udayan · B.-I. Sang

Department of Chemical Engineering, Hanyang

University, Seoul, South Korea

\section{A. K. Pandey · S. H. Kim}

School of Civil and Environmental Engineering, Yonsei

University, Seoul, South Korea

\section{R. Sirohi · S. J. Sim}

Department of Chemical and Biological Engineering,

Korea University, Seoul, South Korea

\section{R. Sirohi · A. Pandey}

Centre for Energy and Environmental Sustainability,

Lucknow, Uttar Pradesh 226 029, India wastewater, and most importantly, they do not participate in the food crop versus energy crop dilemma or debate. An efficient microalgal biorefinery system for the production of lipids and subsequent byproduct for nutraceutical applications could well satisfy the need. But, the current microalgal cultivation systems for the production of lipids and nutraceuticals do not offer techno-economic feasibility together with energy and environmental sustainability. This review article has its main focus on the production of lipids and nutraceuticals from microalgae, covering the current strategies used for lipid production and the major highvalue metabolites from microalgae and their nutraceutical importance. This review also provides insights on the future strategies for enhanced microalgal lipid production and subsequent utilization of microalgal biomass.

\section{N. Sreekumar}

Accubits Invent, Accubits Technologies Inc.,

Thiruvananthapuram, Kerala 695 004, India

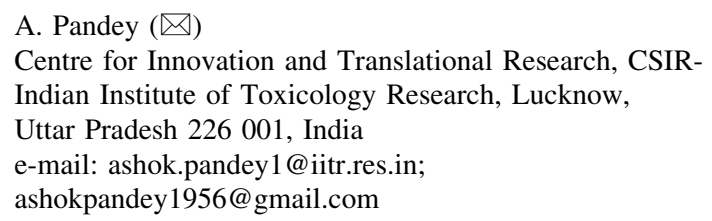




\section{Graphical abstract}

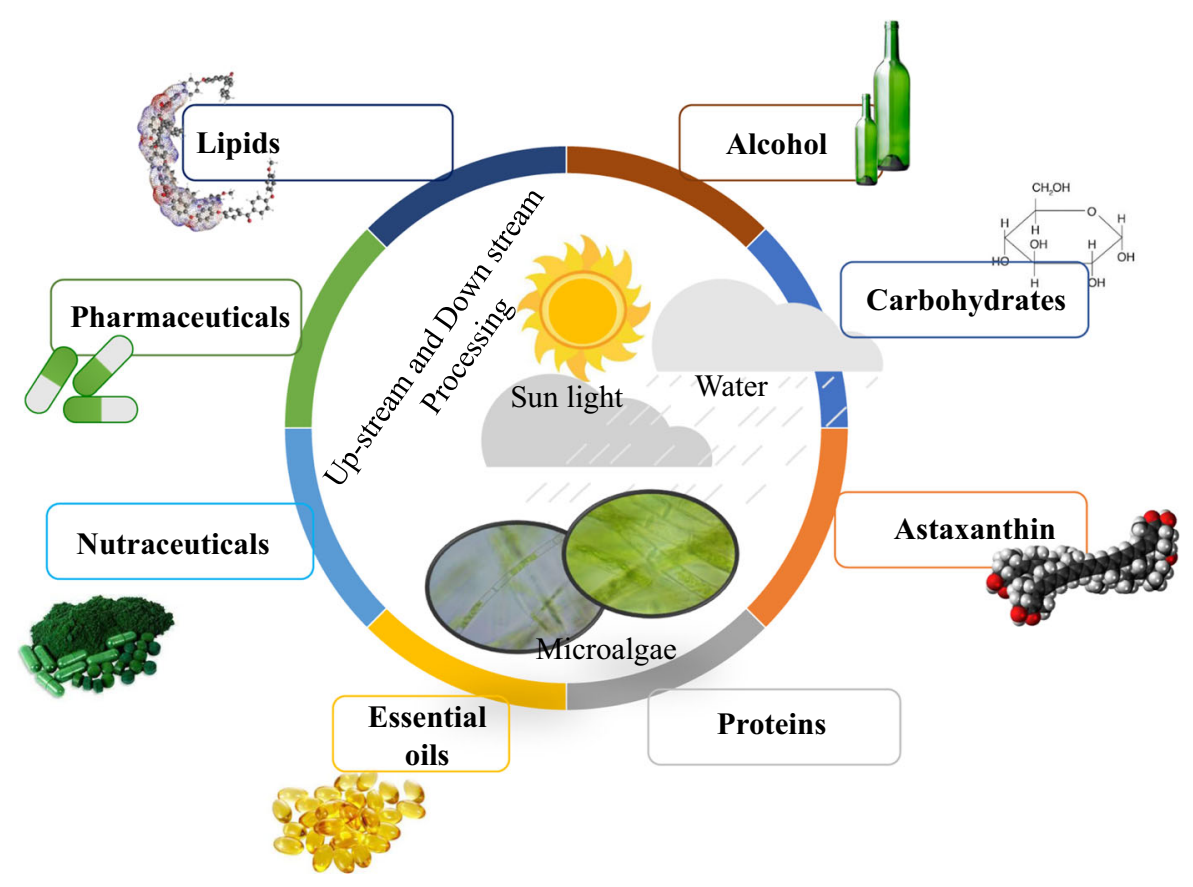

Keywords Microalgae - Lipids - Nutraceuticals ·

Biorefinery $\cdot$ High-value metabolites $\cdot$ Food and feed

$\begin{array}{ll}\text { Abbreviations } \\ \text { EPA } & \text { Eicosapentaenoic acid } \\ \text { DHA } & \text { Docosahexaenoic acid } \\ \text { PUFAs } & \text { Polyunsaturated fatty acids } \\ \text { ALA } & \text { Alpha linoleic acid } \\ \text { PDT } & \text { Photodynamic therapy } \\ \text { DAF } & \text { Dissolved air flotation } \\ \text { TAG } & \text { Triacylglycerol } \\ \text { FAEE } & \text { Fatty acid ethyl esters } \\ \text { FAME } & \text { Fatty acids methyl esters } \\ \text { ppb } & \text { Parts per billion } \\ \text { ppm } & \text { Parts per million } \\ \text { CO } & \text { Carbon dioxide } \\ \text { vvm } & \text { Volume by volume } \\ \text { ha } & \text { Hectare } \\ \text { wt } & \text { Weight } \\ \text { FDA } & \text { Food and Drug Administration } \\ \text { PE } & \text { Phycoerythrin } \\ \text { PEC } & \text { Phycoerythrocyanin } \\ \text { PC } & \text { Phycocyanin } \\ \text { APC } & \text { Allophycocyanin }\end{array}$

Abbreviations

EPA Eicosapentaenoic acid

DHA Docosahexaenoic acid

PUFAs Polyunsaturated fatty acids

PDT Photodynamic therapy

DAF Dissolved air flotation

TAG Triacylglycerol

FAEE Fatty acid ethyl esters

FAME Fatty acids methyl esters

$\mathrm{ppb} \quad$ Parts per billion

ppm Parts per million

$\mathrm{CO}_{2} \quad$ Carbon dioxide

vvm Volume by volume

ha Hectare

PE Phycoerythrin

PEC Phycoerythrocyanin

PC Phycocyanin

Allophycocyanin

\section{Introduction}

During recent years, microalgal cultivation has gained increasing attention for the production of biofuels, functional food, and nutraceuticals (Udayan et al. 2017) with emphasis on adaptation of biorefinery approach, which could be of different types, e.g., biomass-based biorefinery (Fig. 1). A biomass-based biorefinery is a production process and system in which biomass is fractioned to different chemical moieties which are then converted to different endproducts (desired products). This could be achieved via biochemical or thermochemical pathways to produce marketable value-added metabolites, fuels, chemicals, etc. (Hingsamer and Jungmeier 2019; Sirohi et al. 2020; Awasthi et al. 2021). The biorefinery approach can be efficiently utilized for sustainable and efficient product accumulation with increased environmental and economic benefits. The development of a new and efficient biorefinery concept with the already existing industrial approaches can reduce the cost of production as well (Fig. 1). 


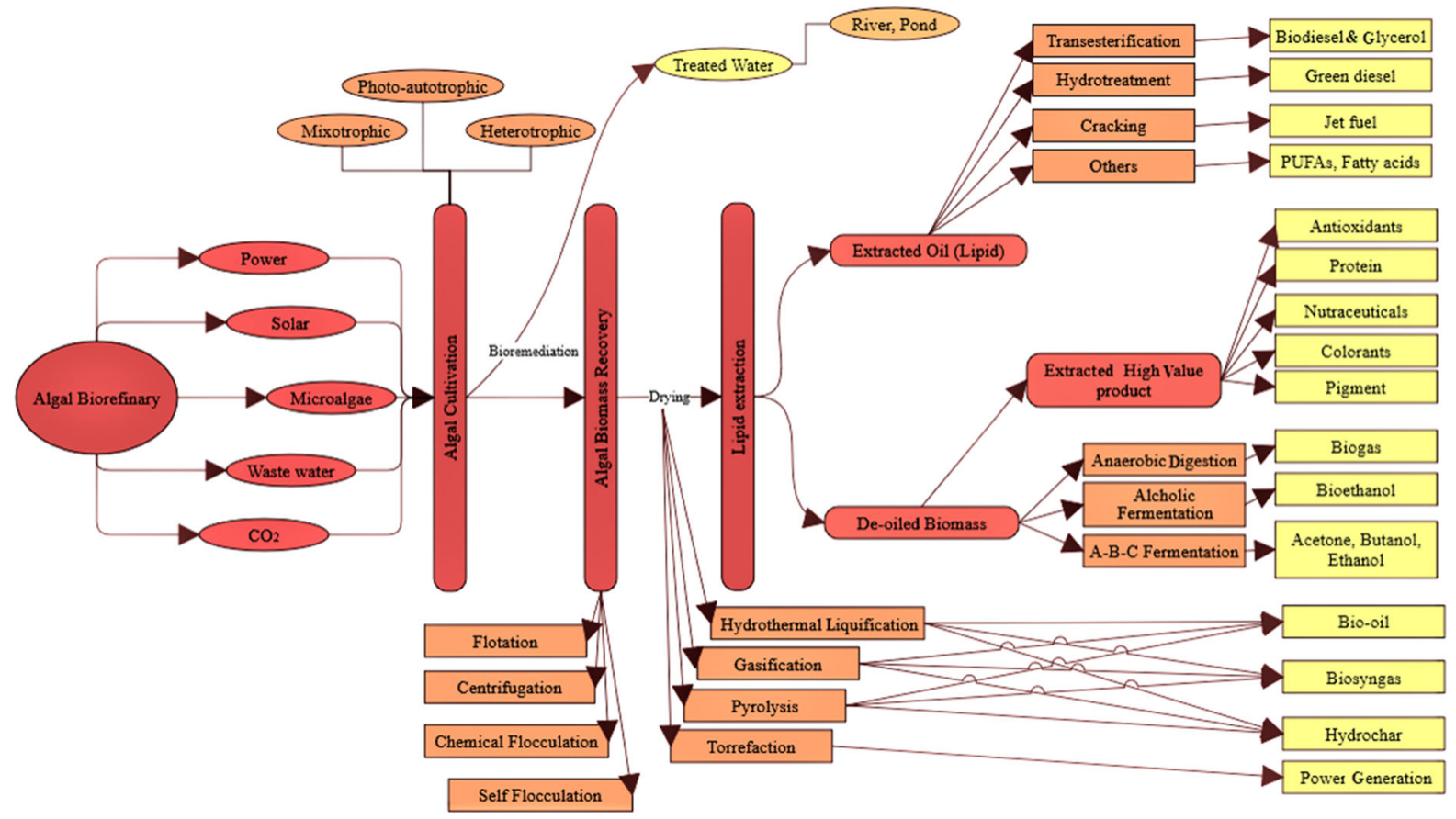

Fig. 1 Process flow diagram for microalgal biorefinery including cultivation, different operation units and downstream processing. The major criteria are the selection of a potential microalgal strain depending on the specific product and supply of low cost nutrients for microalgal growth and metabolite production. Microalgal biorefinery should consider the factors such as (1) better mixing and light penetration, (2) minimum

Microalgae are microscopic photosynthetic organisms and primitive eukaryotic plants on the planet earth. They are unicellular to multi-cellular organisms with different sizes ranging from one to hundred microns. Microalgae have different habitats like freshwater and ocean systems and they play the role of primary producers in the food chain (Udayan et al. 2021). These biological cell factories are the natural nutritional base and primary source for the aquatic food chain. Microalgae are primitive plants belonging to Thallophytes without stems, leaves, and roots and have chlorophyll $a$ as primary photosynthetic pigment. Other examples of Thallophytes are fungi, lichens, and some classes of bryophytes, bacteria, and slime molds. Among these fungi and microalgae are widely studied for biofuel applications. Photosynthetic machinery of land plants is evolved from microalgae and are considered as the primary producers of the aquatic ecosystem. From ancient times, microalgal biomass has been utilized for the production of fuels, food, medicine, etc. investment and operational costs, (3) high biomass production and iv0efficient downstream processing. Downstream processing involves the harvesting of biomass, cell disruption and intracellular metabolite extraction and fractionation of the metabolites to increase the number of commercial products. (*PUFAs polyunsaturated fatty acids)

In the present global scenario, the major fuel sources used are petrol, diesel, coal, and natural gas (Enamala et al. 2018). At the current rate of consumption and overexploitation, it is estimated that the existing fossil fuels will be depleted in the coming 50 years (Martins et al. 2019). The level of greenhouse gases such as $\mathrm{CO}_{2}, \mathrm{CH}_{4}$, and $\mathrm{N}_{2} \mathrm{O}$ have increased tremendously in the atmosphere to $409.8 \mathrm{ppm}$, $1875 \mathrm{ppb}$, and $331.1 \mathrm{ppb}$ as of 2017 compared to the $1800 \mathrm{~s}$, which was $289.9 \mathrm{ppm}, 750.8 \mathrm{ppb}$, and 273 ppb, respectively (Köhler et al. 2017). This alarmingly high increase in $\mathrm{CO}_{2}$ and other greenhouse gas emissions could be reduced by using renewable liquid biofuels.

Liquid biofuels can be used without any major changes compared to the other renewable energy sources such as solar, tidal, and wind energy generation and release of toxic gases into the environment, which contributes to a major reason for global warming which is the major drawback of fossil fuels. The importance of biofuels has increased recently due 
to the above-mentioned reasons. Biofuels are produced from different biomass sources from forestry, agricultural and aquatic sources. The current scenario of producing first-generation biofuels by utilizing food crops such as corn, soybeans, sugar cane, etc., and uncontrolled use of agricultural land for energy production creates an ethical threat of "food crops versus energy crops". Second-generation biofuels mainly utilize nonfood parts of crops including leaves, grass, stem, whole crop maize, lignocellulose biomass, and industrial waste from the food and pulp industry. The use of first and second-generation biofuels is restricted because of their conflict with edible crops, agricultural lands, low market availability, potable water requirement, application of fertilizers, and ecological imbalances (IEA 2017). Several shortcomings of these biofuel feedstocks can be partly solved by switching to third-generation biofuels using algal biomass.

Microalgae have a high rate of lipids production per hectare yield which is 7-31 times higher than other oil crops (Table 1). Microalgal biofuels are non-toxic, highly biodegradable with no sulfur content. The utilization of $\mathrm{CO}_{2}$ by algae during the growth makes it a feasible $\mathrm{CO}_{2}$ mitigation agent from power stations and industrial plants, which could lead to environmental pollution (Sreekumar et al. 2018; Joun et al. 2021; Sirohi et al. 2021b). Microalgae represent primitive land plants and depend on photosynthesis for the production of chemical energy from solar energy. The chemical energy synthesized by microalgae is stored in the oils, proteins, and carbohydrates. While considering biofuels, the lipid yield from a particular species highly affects its energy production efficiency (Sreekumar et al. 2016). Microalgae have a higher growth rate, high photosynthetic efficiency, adaptability to harsh environmental stress conditions, and can grow in wastewater with high nutrient uptake ability. Also, the simple cellular structure simplifies the technical limitations of downstream processing and product recovery, which makes it a prominent feedstock for nutraceutical production (Costa et al. 2019).

It has been reported that microalgae can contribute around $40-50 \%$ of the atmospheric oxygen and subsequently utilize $\mathrm{CO}_{2}$, nitrogen, and phosphate to grow autotrophically, which makes microalgae attractive for $\mathrm{CO}_{2}$ mitigation and reduced environmental pollution (Costa et al. 2019). Microalgal biofuel has an advantage over the petroleum feedstock stock because of its high oxygen content (10-12\%) over petroleum fuel (4\%). Higher oxygen content helps to speed up the combustion process. It has been estimated that around $16 \%$ of global transport fuel requirements will be satisfied by biofuels in 2040 (Energy and Change 2017). Currently, many microalgal production systems are focused on the production of lipids and their subsequent use as nutraceuticals (Table 2), but the major problem facing all the industries is low biomass production and high downstream processing costs. Therefore, it is indeed necessary to understand the problems in commercial lipid and nutraceutical production from microalgae. Especially during the Covid19 pandemic situation the world is in search for efficient immune boosters and health promoting substances, microalgal metabolites have many health benefits including immune system boosting activities (Udayan et al. 2021). Moreover, many studies have focused on the biofuel applications of microalgae rather than its food and nutritional applications (Table 2) Therefore, the main objective of this study is to give insights on the current methods used for the production of lipids from microalgae, their challenges in commercial production and future of microalgae in nutraceutical industries.

\section{Production of lipids by microalgae}

Microalgae have active participation in overtaking the transport fuel sector if cost-effective and efficient large-scale production systems could be achieved. The development of a cost-effective and coherent biorefinery system for biofuel production from microalgae along with high-value metabolites for food and feed applications is very necessary. It has been reported that the total cost of production of dry microalgae ranges from 2 to 10 USD per kg based on a different mode of cultivation (Hingsamer and Jungmeier 2019). Taking USD 2 per kg and 25\% oil content, the oil cost will be USD 8 per $\mathrm{kg}$. In the last decade, crude oil has traded in the range of USD 60-140 per barrel of $159 \mathrm{~L}$ (Hingsamer and Jungmeier 2019). The crude oil price must rise to more than USD 1272 per barrel or algae production cost has to reduce to $0.2 \mathrm{USD}$ per $\mathrm{kg}$ if microalgal oil has to become competitive. This difference in cost of production can only be solved by technological break-through. A critical 
Table 1 Comparison of oil production between oil crops and microalgae

\begin{tabular}{|c|c|c|c|c|c|c|}
\hline $\begin{array}{l}\text { Species } \\
\text { Oil crop }\end{array}$ & $\begin{array}{l}\text { Galon } \\
\text { oil/accre }\end{array}$ & $\begin{array}{l}\text { Fat content } \\
(\%)\end{array}$ & $\begin{array}{l}\text { SFA } \\
(\% \mathrm{FA})\end{array}$ & $\begin{array}{l}\text { MUFA } \\
(\% \text { FA })\end{array}$ & $\begin{array}{l}\text { PUFA } \\
(\% \text { FA })\end{array}$ & References \\
\hline Soybean & 46 & $20-25$ & 15.9 & 24.8 & 59.3 & $\begin{array}{l}\text { Dorni et al. (2018), Tamagno } \\
\text { et al. (2020) }\end{array}$ \\
\hline Rapeseed & 122 & $45-50$ & 18.2 & 59.3 & 21.7 & Hossain et al. (2019) \\
\hline Peanut & 109 & $45-55$ & 19.3 & 53.8 & 27.0 & $\begin{array}{l}\text { Dorni et al. (2018), Wang } \\
\text { et al. (2012) }\end{array}$ \\
\hline Sunflower & 98 & $35-50$ & 11.4 & 25.9 & 62.7 & $\begin{array}{l}\text { Dorni et al. (2018), } \\
\text { Ebrahimian et al. (2019) }\end{array}$ \\
\hline Palm & 23 & $46-50$ & 44.8 & 43.6 & 11.5 & $\begin{array}{l}\text { Dorni et al. (2018), Ong et al. } \\
\text { (2011) }\end{array}$ \\
\hline Mustard & 59 & 31 & 5.7 & 67.0 & 27.3 & Dorni et al. (2018) \\
\hline Cottonseed & 33 & $28-45$ & 28.2 & 19.7 & 52.2 & $\begin{array}{l}\text { Dorni et al. (2018), Liu et al. } \\
\text { (2020) }\end{array}$ \\
\hline Corn & 18 & $4-5$ & 16.6 & 33.7 & 49.7 & Dorni et al. (2018) \\
\hline Coconut & 276 & $65-75$ & 90.8 & 7.2 & 1.9 & Dorni et al. (2018) \\
\hline Safflower & 80 & $32-40$ & 9.2 & 14.0 & 76.8 & $\begin{array}{l}\text { Dorni et al. (2018, } \\
\text { Ebrahimian et al. (2019) }\end{array}$ \\
\hline Microalgae & $\begin{array}{l}\text { Oil content } \\
(\%)\end{array}$ & $\begin{array}{l}\text { Lipid } \\
\text { productivity } \\
\left(\mathrm{mgL}^{-1} \text { day }^{-1}\right.\end{array}$ & & & & \\
\hline $\begin{array}{l}\text { Phaeodactylum } \\
\text { tricornutum }\end{array}$ & $18-57$ & 44.80 & 20.2 & 25.3 & 49.8 & Deshmukh et al. (2019) \\
\hline Schizochytrium sp. & $50-77$ & $30-40$ & 19.0 & 27.0 & 30.0 & $\begin{array}{l}\text { Sajjadi et al. (2018), } \\
\text { Menegazzo and Fonseca } \\
\text { (2019) }\end{array}$ \\
\hline Chlorella sp. & $28-53$ & 42.1 & 26.3 & 70.9 & 12.4 & Ferreira et al. (2019) \\
\hline Botryococcusbraunii & $25-75$ & 5.50 & 11.7 & 63.1 & 25.2 & Ferreira et al. (2019) \\
\hline Nannochloropsis $p$ & $31-68$ & 54.80 & 10.4 & 39.5 & 36.9 & Deshmukh et al. (2019) \\
\hline Scenedesmus obliquus & $30-50$ & $40-54$ & 18.6 & 25.9 & 30.0 & Ferreira et al. (2019) \\
\hline Pavlova salina & $12-30$ & 34.8 & 32.0 & 5.0 & 41.0 & Deshmukh et al. (2019) \\
\hline Chlamydomonas sp. & $21-27$ & $10-20$ & 63.9 & 14.1 & 6.7 & Deshmukh et al. (2019) \\
\hline Phorphyridium cruentum & $9-14$ & 34.80 & 31.1 & 5.0 & 40.8 & Deshmukh et al. (2019) \\
\hline
\end{tabular}

understanding of the cultivation parameters will help to improve lipid and biomass production from microalgae and subsequent cost reduction methods are indeed necessary to make microalgae as a renewable and ecofriendly agent for fuels, chemicals and nutraceuticals applications.

The storage of oils and fatty acid depends upon the microalgae species and cultivation conditions including temperature, light availability, and medium constitution (Gifuni et al. 2019). Temperature, light, and nitrogen concentration are the cultivation factors that impart direct influence on the lipid and fatty acids content in microalgae (Sibi et al. 2016). Among the nutrients, nitrogen concentration has been known to critically impact lipid accumulation such that nitrogen limitation increases the lipid content in microalgae (Viegas et al. 2015; Sulochana and Arumugam 2020). Nutrient stress hinders cell growth but some species still synthesize fatty acids which, under such conditions, are not utilized in membrane lipid formation and instead accumulate as triglycerides (Ratomski and Hawrot-Paw 2021). Oils from microalgae are excellent sources for bioenergy and biomaterials production. Depending upon the species and cultivation 
Table 2 Summary of literature about the enhanced lipid production in microalgae (From 2017)

\begin{tabular}{|c|c|c|c|}
\hline Year & References & Objective of the study & Main focus \\
\hline 2017 & $\begin{array}{l}\text { Chen et al. } \\
\text { (2017) }\end{array}$ & $\begin{array}{l}\text { Environmental stress and stress tolerance } \\
\text { of microalgae for enhanced lipid } \\
\text { production }\end{array}$ & Genetic approach and cultivation \\
\hline 2017 & Chu (2017) & $\begin{array}{l}\text { Strategies for enhanced lipid production in } \\
\text { microalgae }\end{array}$ & $\begin{array}{l}\text { Selection of microalgal strain, manipulation of cultivation } \\
\text { conditions, wastewater treatment, co-culturing of } \\
\text { microalgae }\end{array}$ \\
\hline 2017 & $\begin{array}{l}\text { Kim et al. } \\
\text { (2018) }\end{array}$ & $\begin{array}{l}\text { Application of microfluidics for the } \\
\text { selection of highly efficient microalgal } \\
\text { strain }\end{array}$ & Strain selection, microfluidics, mutation \\
\hline 2017 & $\begin{array}{l}\text { Zhu et al. } \\
\text { (2016) }\end{array}$ & $\begin{array}{l}\text { Molecular approach for lipid production in } \\
\text { microalgae for biodiesel applications }\end{array}$ & $\begin{array}{l}\text { Molecular synthesis of lipids and fatty acids, strategies for } \\
\text { improving lipid production using molecular approach }\end{array}$ \\
\hline 2018 & $\begin{array}{l}\text { Sharma et al. } \\
\text { (2018) }\end{array}$ & $\begin{array}{l}\text { Application of microalgae for biofuel } \\
\text { production }\end{array}$ & $\begin{array}{l}\text { Genetic engineering for the manipulation of oil synthesis and } \\
\text { biomass production, genome editing for strain improvement }\end{array}$ \\
\hline 2018 & $\begin{array}{l}\text { Yun et al. } \\
\text { (2018) }\end{array}$ & $\begin{array}{l}\text { Wastewater as a nutrient source for } \\
\text { biomass production in open raceway } \\
\text { ponds }\end{array}$ & Optimization of cultivation conditions \\
\hline 2018 & $\begin{array}{l}\text { Shin et al. } \\
\quad(2018)\end{array}$ & $\begin{array}{l}\text { Strategies for enhancing economic } \\
\text { viability of microalgae for lipid } \\
\text { production }\end{array}$ & $\begin{array}{l}\text { Species dependent factors, optimization of physiochemical } \\
\text { properties, culture system improvement }\end{array}$ \\
\hline 2018 & $\begin{array}{l}\text { Sajjadi et al. } \\
\text { (2018) }\end{array}$ & $\begin{array}{l}\text { Enhancement of lipid and fatty acid } \\
\text { production in microalgae }\end{array}$ & $\begin{array}{l}\text { Taxonomic characterization of microalgae, environmental } \\
\text { factors affecting lipid and fatty acid production in } \\
\text { microalgae }\end{array}$ \\
\hline 2019 & $\begin{array}{l}\text { Nagappan et al. } \\
\text { (2019) }\end{array}$ & $\begin{array}{l}\text { Two stage microalgal cultivation systems } \\
\text { for biofuel applications }\end{array}$ & Modification of cultivation conditions \\
\hline 2019 & $\begin{array}{l}\text { Piligaev et al. } \\
\text { (2019) }\end{array}$ & $\begin{array}{l}\text { Production and catalytic processing of } \\
\text { microalgal lipids for biofuel applications }\end{array}$ & $\begin{array}{l}\text { Strain selection, modification of media composition, use of } \\
\text { wastewater for lipid production, biodiesel applications }\end{array}$ \\
\hline 2019 & $\begin{array}{l}\text { Menegazzo and } \\
\text { Fonseca } \\
(2019)\end{array}$ & $\begin{array}{l}\text { Recovery of microalgal biomass and lipid } \\
\text { extraction }\end{array}$ & $\begin{array}{l}\text { Harvesting of microalgal biomass and lipid extraction } \\
\text { methods }\end{array}$ \\
\hline 2020 & $\begin{array}{l}\text { Nguyen et al. } \\
\text { (2020) }\end{array}$ & $\begin{array}{l}\text { Molecular approach for lipid induction in } \\
\text { microalgae }\end{array}$ & CRISPR-Cas9 technology \\
\hline 2020 & $\begin{array}{l}\text { Poh et al. } \\
\text { (2020) }\end{array}$ & $\begin{array}{l}\text { Application of stress conditions for lipid } \\
\text { induction in microalgae }\end{array}$ & Induction of stress conditions \\
\hline 2020 & $\begin{array}{l}\text { Aziz et al. } \\
\quad(2020)\end{array}$ & $\begin{array}{l}\text { Two stage cultivation for enhanced } \\
\text { biomass and lipid production in } \\
\text { microalgae }\end{array}$ & Culturing parameters and harvesting \\
\hline 2020 & $\begin{array}{l}\text { Bhatia et al. } \\
\text { (2021) }\end{array}$ & Wastewater based microalgal biorefinery & $\begin{array}{l}\text { Different types of wastewater, cultivation systems, harvesting } \\
\text { techniques }\end{array}$ \\
\hline 2021 & $\begin{array}{l}\text { Lee et al. } \\
\quad(2020)\end{array}$ & $\begin{array}{l}\text { Lipid extraction for microalgal biofuel } \\
\text { production }\end{array}$ & Biomass production, harvesting, lipid extraction \\
\hline 2021 & $\begin{array}{l}\text { Orejuela- } \\
\text { Escobar et al. } \\
(2021)\end{array}$ & $\begin{array}{l}\text { Biomaterials from microalgae for } \\
\text { biorefineries }\end{array}$ & $\begin{array}{l}\text { Bioactive compounds from microalgae, health benefits, } \\
\text { industrial applications }\end{array}$ \\
\hline 2021 & $\begin{array}{l}\text { Udayan et al. } \\
\text { (2021) }\end{array}$ & Industrial applications of microalgae & $\begin{array}{l}\text { High value metabolites from microalgae, health benefits, } \\
\text { industrial applications }\end{array}$ \\
\hline
\end{tabular}

conditions, microalgae oil production can be as high as $75 \%$ of their biomass. This could be further enhanced by inducing modifications in the microalgae life cycle, cultivation parameters, and extraction and recovery methods (Chen et al. 2011; Abreu et al. 2012). However, the application of such modifications and 
selection of appropriate recovery and extraction strategies can be a challenging task to be performed at an industrial scale because of the associated technical and economic obstructions. Microalgae with the highest lipid content, ranging from 10 to $67 \%$, belong to Chlorella, Dunaliella, and Scenedesmus species (Islam et al. 2013; Nascimento et al. 2013).

Strategies for enhanced lipids production in microalgae

The growth and constitution of microalgae are substantially influenced by the environmental factors and composition of the medium in small-scale and large-scale culturing systems. The amount of nutrients added to microalgae culture, besides other parameters, decides the quantity and quality of biomass and metabolites obtained. At commercial scale production where the focus is on the synthesis of biomolecules, the amount of micro and macronutrients are varied to minimize the microalgae growth and increase the accumulation of metabolites of interest. Carbon, nitrogen, phosphorus along some micronutrients are the essential nutrients that assure minimum microalgae growth conditions (Chu 2017). In addition to this wastewater has also been used to increase the lipid productivity in microalgae with a combination of other methods like light, temperature, salinity, nutrient stress, etc. (Table 3).

In the case of lipids production, the production performance is mainly evaluated based on lipid content i.e. \% lipid per biomass dry weight and lipid productivity is the amount of lipid produced per liter working volume per day. Accumulation of oils in microalgae cells is favored during conditions of stress which leads slower growth rate of cells and this aspect is particularly important when the focus is on lipid productivity (Aratboni et al. 2019). Production efficiency of most microalgae products including lipids is critically influenced by factors like light intensity and illumination pattern, temperature, and nitrogen source. Besides these factors, $\mathrm{pH}$, salinity, and mineral salts are also major stimuli affecting lipid production (Zhu et al. 2016). In a study, the high lipid content of about $32.5 \%$ was obtained from biomass of Chlorella sp. cultivated with $\mathrm{MgSO}_{4}$ (150 ppm), salinity (12.5\%) and low light intensity, however, the lipid content noticeably decreased to $12.5 \%$ on lowering the concentration of salt and increasing salinity and light intensity (Shekh et al. 2016). Carbon is a macronutrient and is essential for any cell cultivation because it forms the basic constitution of major biomolecules i.e. proteins, carbohydrates, lipids, and nucleic acids as well as other organic substances like vitamins. Nitrogen too has a major role in protein formation and its adequate presence in culture medium ensures sufficient concentrations of proteins, carotenoids, and chlorophyll (Table 3).

\section{Nutrient stress}

Nitrogen limitation is the most efficient stimuli for creating stress conditions in cells and therefore enhances lipid accumulation in microalgae (Sulochana and Arumugam 2020). A lipid content study by $\mathrm{Hu}$ and colleagues showed that under conditions of nitrogen limitation, the lipid content of microalgae varies from 10 to $20 \%$ (Hu et al. 2008). The same study reported that stress conditions in cyanobacteria caused less than $10 \%$ lipid content production in cells. A twostage nitrogen limitation and a one-stage limitation method are the two main approaches utilized to encourage lipid aggregation in microalgae cells. In the two-stage strategy, the cells are initially provided with adequate nitrogen conditions for a definite time to incite cell growth. The second step is to collect the grown cells and expose them to nitrogen limited conditions, encouraging lipid accumulation. On the other hand, in one-stage approach a defined level is set for the initial nitrogen concentration such that the time after which nitrogen starvation occurs could be monitored. The culture cells initially grow and as the nitrogen content in the medium reduces over time, the microalgae culture will switch to the nitrogen limitation stage on its own.

Under normal growth conditions, microalgae produce high biomass but will not accumulate high-value metabolites like lipids (Piligaev et al. 2019). Under nutrient stress conditions, microalgae will change the metabolism of fatty acids towards the synthesis and accumulation of triacylglycerol's which consists of up to $80 \%$ of the total lipid content in the cell (Ratomski and Hawrot-Paw 2021). When nitrogen is limited in the cultivation medium, microalgae will accumulate large amounts of lipids but due to the lack of nitrogen, the cells will not produce sufficient amounts of proteins which results in lower biomass production. Chlorophyll content also changes under the nutrient 
Table 3 Strategies for enhanced lipid productivity in microalgal biorefinery

\begin{tabular}{|c|c|c|c|}
\hline Strategy & Microalgae used & $\begin{array}{l}\text { Lipid productivity (g } \\
\mathrm{L}^{-1} \text { day }^{-1} \text { ) }\end{array}$ & References \\
\hline \multirow[t]{3}{*}{ Salinity stress } & Scenedesmus sp. & 0.607 & Xia et al. (2013) \\
\hline & $\begin{array}{l}\text { Nannochloropsis } \\
\quad \text { oculata }\end{array}$ & 0.324 & $\begin{array}{l}\text { Shokravi et al. } \\
(2020)\end{array}$ \\
\hline & Dunaliella salina & 0.565 & $\begin{array}{l}\text { Abomohra et al. } \\
\text { (2020) }\end{array}$ \\
\hline \multirow[t]{2}{*}{ Salinity stress + nitrogen starvation } & Tetraselmis sp. & 0.285 & Park et al. (2018) \\
\hline & Chlorella vulgaris & 0.8 & $\begin{array}{l}\text { Mirizadeh et al. } \\
\text { (2020) }\end{array}$ \\
\hline Phytohormones & Chlorella sorokiniana & 0.502 & Guldhe et al. (2019) \\
\hline Phytohormones + nitrogen starvation & Chlorella sorokiniana & 0.69 & Babu et al. (2017) \\
\hline Combination of $\mathrm{NaCl} / \mathrm{CaCl}_{2}$ & $\begin{array}{l}\text { Chamydomonas } \\
\text { reinhardtii }\end{array}$ & 0.109 & Hang et al. (2020) \\
\hline Salinity + nitrogenstarvation + wastewater & Chlorella vulgaris & 0.080 & $\begin{array}{l}\text { Mirizadeh et al. } \\
\text { (2020) }\end{array}$ \\
\hline Muncipalwastewater + seawater & $\begin{array}{l}\text { Phaeodactylum } \\
\text { tricornutum }\end{array}$ & 0.054 & Wang et al. (2019) \\
\hline $\begin{array}{l}\text { Two stage photoautotrophic and mixotrophic } \\
\text { cultivation }\end{array}$ & Chlorella vulgaris & 0.108 & $\begin{array}{l}\text { Shokravi et al. } \\
\text { (2020) }\end{array}$ \\
\hline Farm wastewater & Chlorella sorokiniana & 0.083 & $\begin{array}{l}\text { Shokravi et al. } \\
(2020)\end{array}$ \\
\hline Wastewater + glycerol & Chlorella vulgaris & 0.163 & Ma et al. (2016) \\
\hline Wastewater & Chlorella vulgaris & 0.02 & Ge et al. (2018) \\
\hline
\end{tabular}

stress conditions, which is the indicator of photosynthesis and photochemical processes during which the energy accumulated in ATP is generated (Rai et al. 2015). Therefore, the supply of appropriate doses of nutrients is indeed necessary for achieving high production of lipids as well as high efficiency of biomass production along with optimal culture conditions like temperature, $\mathrm{pH}$, light, and mixing (Ratomski and Hawrot-Paw 2021). The supply of nutrients for the production of microalgal biomass and lipids can be associated with the purification of the aquatic environment and bioremediation.

\section{Light intensity}

The types of the light source, intensity, duration of illumination as well as wavelength range are known to have an acute impact on lipid productivity and biomass growth. In laboratory and closed cultivation systems, artificial lights are used to simulate natural conditions with the help of fluorescent lamps. For increased lipid production, light distribution should be uniform within the photobioreactor. However, to an extent, practically this is unattainable because as more cells grow (or when biofilm forms) in the reactor, the cells on top layers mask those in lower layers thus reducing light penetration to them (Chia et al. 2018). Proper mixing of cells within the reactor is one way to overcome light penetration issues while keeping in mind that the mixing device does not cause cell shear. It has been reported that the content of neutral storage lipids increases while that of total polar lipids decreases when the culture is exposed to high light intensity (Seo et al. 2017). Increase light supplementation favors the formation of short-chain fatty acids, thus, demonstrating its role in deciding the level of fatty acid saturation (Islam et al. 2013). Application of light intensity of $700 \mu \mathrm{mol}$ photons $/ \mathrm{m}^{2} / \mathrm{s}$ to Nannochloropsis culture resulted in a lipid accumulation of $47 \%$ of dry weight (Pal et al. 2011). Accumulation of lipids in Scenedesmus sp. was found to be increased to 11-fold when the light intensity has been increased 
to $400 \mu \mathrm{mol}$ photons $/ \mathrm{m}^{2} / \mathrm{s}$ from $250 \mu \mathrm{mol}$ photons/ $\mathrm{m}^{2} / \mathrm{s}$ (Liu et al. 2012). Providing light intensity of $1500 \mu \mathrm{mol}$ photons $/ \mathrm{m}^{2} / \mathrm{s}$ to Ettlia $\mathrm{sp}$. has resulted in the highest lipid accumulation of $291.4 \mathrm{mg} / \mathrm{L} /$ day (Seo et al. 2017).

\section{Temperature}

When considering biomass growth, the temperature of microalgal cultures commonly ranges from 15 to $26{ }^{\circ} \mathrm{C}$. Metabolism is impeded by high temperatures and carbon bioconversion is limited by $20-30 \%$ (Cheah et al. 2015), although some strains of Chlorella show contradicting behavior by reportedly tolerating temperatures as high as $42{ }^{\circ} \mathrm{C}$. Culture temperatures below $15{ }^{\circ} \mathrm{C}$ are also considered unsuitable for photosynthesis and growth. High culture temperature has been reported to increase saturated fatty acids (Nadzir et al. 2018) and lipid content as is observed in cases of Nannochloropsis salina and Ochromonas danica although, cultures of Chlorella sorokiniana showed almost no variation in lipid contents with changing temperatures (Chowdury et al. 2020). Even though high temperatures increase saturated fatty acids, the unsaturated fatty acids percentage reportedly decreases (Chowdury et al. 2020).

\section{Carbon dioxide}

Apart from light, temperature, and nitrogen concentration, the amount of $\mathrm{CO}_{2}$ also significantly influences microalgae growth and lipid accumulation (Table 4). $\mathrm{CO}_{2}$ dissolved in the medium is consumed in the presence of light but if the concentration of $\mathrm{CO}_{2}$ in the medium gets high, it can inhibit the growth of microalgae (Muylaert et al. 2017). The growth inhibition can be attributed to the formation of carbonic acid in the media because of the increased dissolution of $\mathrm{CO}_{2}$, which results in the drop of media $\mathrm{pH}$. As a result of $\mathrm{pH}$ reduction, the growth of some species gets slowed down and they require optimal $\mathrm{pH}$ between 7.9 and 8.3 for survival (Zhao and Su 2014). Strategic application of various stress stimuli in culture is used for enhancing the production of lipid or other molecules of interest, the strategies varying according to microalgae employed (Wang et al. 2014). When microalgal culture is supplemented with high concentrations of $\mathrm{CO}_{2}$ a portion of the carbon can be used by the cells for participating in photosynthesis and the

Table 4 Effect of $\mathrm{CO}_{2}$ on lipid accumulation in microalgae

\begin{tabular}{|c|c|c|c|}
\hline Microalgae & $\mathrm{CO}_{2}$ concentration & Lipid accumulation & References \\
\hline $\begin{array}{l}\text { Chlorella sp. BTA } \\
9031\end{array}$ & $3 \%(\mathrm{v} / \mathrm{v})$ & $\begin{array}{l}\text { Accumulated } 25 \% \text { of lipid as a percentage of } \\
\text { dry cell weight }\end{array}$ & $\begin{array}{l}\text { Aratboni et al. } \\
\text { (2019) }\end{array}$ \\
\hline $\begin{array}{l}\text { Chlamydomonas sp. } \\
\text { JSC4 }\end{array}$ & $4 \%(\mathrm{v} / \mathrm{v})$ & $\begin{array}{l}\text { Generated maximum lipid content }(65.3 \%) \text { and } \\
\text { productivity }(169.1 \mathrm{mg} / \mathrm{L} / \text { day })\end{array}$ & $\begin{array}{l}\text { Aratboni et al. } \\
\text { (2019) }\end{array}$ \\
\hline $\begin{array}{l}\text { Chlorococcum } \\
\text { littorale }\end{array}$ & $5 \%(\mathrm{v} / \mathrm{v})$ & Lipid content increased up to $34 \%$ wt & $\begin{array}{l}\text { Mondal et al. } \\
\text { (2016) }\end{array}$ \\
\hline $\begin{array}{l}\text { Scenedesmus } \\
\text { obliquus } C N W-N\end{array}$ & $\begin{array}{l}\text { The optimal } \mathrm{CO}_{2} \text { consumption rate } \\
\text { was } 1420.6 \mathrm{mg} / \mathrm{L} / \text { day }\end{array}$ & $\begin{array}{l}\text { The highest productivity of lipid }(140.35 \mathrm{mg} / \\
\mathrm{L} / \text { day) is achieved }\end{array}$ & Ho et al. (2017) \\
\hline $\begin{array}{l}\text { Synechocystis sp. } \\
\text { PCC6803 }\end{array}$ & $3 \%(\mathrm{v} / \mathrm{v})$ & $\begin{array}{l}\text { The total lipid content increased up to } 14 \% \text { of } \\
\text { dry weight }\end{array}$ & $\begin{array}{l}\text { Cuellar-Bermudez } \\
\text { et al. (2015) }\end{array}$ \\
\hline Porosira glacialis & $20-25 \%$ levels of $\mathrm{CO}_{2}$ & $\begin{array}{l}\text { The total lipid content increased from } 8.91 \text { to } \\
10.57 \% \text { in cell dry mass }\end{array}$ & $\begin{array}{l}\text { Artamonova et al. } \\
\text { (2017) }\end{array}$ \\
\hline Attheyolongicornis & $20-25 \%$ levels of $\mathrm{CO}_{2}$ & $\begin{array}{l}\text { Did not show any significant increase in total } \\
\text { lipid content }\end{array}$ & $\begin{array}{l}\text { Artamonova et al. } \\
\text { (2017) }\end{array}$ \\
\hline $\begin{array}{l}\text { Nannochloropsis } \\
\text { oculata }\end{array}$ & $3 \%(\mathrm{v} / \mathrm{v})$ & Demonstrated high lipid content (53.2 wt.\%) & $\begin{array}{l}\text { Udayan et al. } \\
\text { (2017) }\end{array}$ \\
\hline Scenedesmus sp. & $10 \% \mathrm{CO}_{2}$ & $\begin{array}{l}\text { Lipid productivity reached up to } 20.65 \mathrm{mg} / \\
\text { L/day }\end{array}$ & Yoo et al. 92010) \\
\hline Chlorella vulgaris & $30 \% \mathrm{CO}_{2}$ & The highest lipid content $45.68 \%$ is obtained & $\begin{array}{l}\text { Aratboni et al. } \\
(2019)\end{array}$ \\
\hline
\end{tabular}


remaining carbon could be converted to carbonic acid. Production of carbonic acid will result in the acidification of the medium which could affect cell growth and metabolic pathways.

\section{Extraction of lipids}

The lipids present in microalgae cells are polar membrane lipids (phospholipids and glycolipids) and non- polar reserve lipids (triacylglycerols, glycerides, carotenoids, sterols) (Ryckebosch et al. 2014). High fatty acid content and presence of only glycerol as other constituent makes triacylglycerols a preferred choice for biodiesel production (Breuer et al. 2013). The amount of lipid obtained from a cell is influenced by the employed cell disruption and extraction method. The yield depends upon fatty acids solubility, solvent characteristics, and solvent potential to permeate the disrupted cell membrane. To minimize lipid loss and degradation and to maintain economic feasibility, it is important to select a method that is fast, sensitive and efficient (Koutra et al. 2020). After cell disruption and lipid release, the cell debris is separated by techniques like filtration and centrifugation and the lipids are removed from the extraction solvent by techniques such as distillation and evaporation (Halim et al. 2012). Organic solvents or supercritical fluid are mostly used in lipid extraction techniques (Table 5) (Li et al. 2014; Baumgardt et al. 2016; Khoo et al. 2020). Direct transesterification into fatty acids is an emerging technique incorporating lipid extraction and transesterification in a single process (Fig. 2) (Torres et al. 2017). Lipid extraction from microalgae has been reported by the use of different physical and chemical processes like solvent extraction, ball mill, microwave, ultrasound, and results of each method varying with the microalgae species (Table 6) (Hidalgo et al. 2016; Lee et al. 2020).

Sequential extraction of microalgal lipids can also be considered as a new strategy for the efficient extraction of lipids (Lee et al. 2020). Such integration in unit operations can be used to achieve effective extraction of lipids with a minimum number of processing steps (Table 6). In this method, the solvents used for the extraction can penetrate the cell membrane and efficiently interact with the intracellular

Table 5 Solvent assisted lipid extraction: Pros and Cons in biorefinery approach

\begin{tabular}{|c|c|c|c|}
\hline $\begin{array}{l}\text { Type of } \\
\text { solvent }\end{array}$ & Pros & Cons & References \\
\hline Ionic liquids & $\begin{array}{l}\text { High thermal stability, selectivity can be } \\
\text { adjusted, nonflammable, can be used for wet } \\
\text { biomass directly }\end{array}$ & $\begin{array}{l}\text { High toxicity, high cost of chemicals, requires } \\
\text { complex steps for the purification of lipids } \\
\text { from ionic lipids, more studies are needed } \\
\text { for technical viability in scale up process }\end{array}$ & $\begin{array}{l}\text { Wahidin et al. } \\
\text { (2018) }\end{array}$ \\
\hline $\begin{array}{l}\text { Supercritical } \\
\text { fluid } \\
\text { extraction }\end{array}$ & $\begin{array}{l}\text { Low toxicity, rapid process, easy end product } \\
\text { recovery, safe for thermal labile compounds, } \\
\text { because of the low critical temperature, } \\
\text { selectivity can be adjusted by varying the } \\
\text { temperature and pressure, applicable for wet } \\
\text { biomass directly without any drying process }\end{array}$ & $\begin{array}{l}\text { High operating cost, high cost of equipment, } \\
\text { polar co-solvent need additional polar } \\
\text { solvent extraction }\end{array}$ & Patel et al. (2018) \\
\hline $\begin{array}{l}\text { Organic } \\
\text { solvent }\end{array}$ & $\begin{array}{l}\text { Simple method, rapid extraction, easy } \\
\text { recovery of end product by distillation or } \\
\text { heating }\end{array}$ & $\begin{array}{l}\text { High flammability, high toxicity, need dried } \\
\text { microalgal biomass which will make the } \\
\text { process more complex }\end{array}$ & $\begin{array}{l}\text { Callejón et al. } \\
\text { (2020), } \\
\text { Lakshmikandan } \\
\text { et al. (2020) }\end{array}$ \\
\hline $\begin{array}{l}\text { Deep } \\
\text { eutectic } \\
\text { solvents } \\
\text { (DES) }\end{array}$ & $\begin{array}{l}\text { Biodegradable, low toxicity, low volatility, } \\
\text { simple process, low material cost, properties } \\
\text { can be changed by adjusting hydrogen bond } \\
\text { donors and acceptors }\end{array}$ & $\begin{array}{l}\text { Low decomposition temperature, further } \\
\text { studies are needed to explore the potential of } \\
\text { DES, technical viability at large scale } \\
\text { needed to be explore }\end{array}$ & Sed et al. (2018) \\
\hline $\begin{array}{l}\text { Switchable } \\
\text { solvents }\end{array}$ & $\begin{array}{l}\text { Switchable polarity and hydrophobicity, } \\
\text { efficient lipid extraction, easy recovery of } \\
\text { end product, can be used for wet biomass } \\
\text { directly }\end{array}$ & $\begin{array}{l}\text { High water sensitivity, technical viability need } \\
\text { to be explored for large scale applications }\end{array}$ & $\begin{array}{l}\text { Al-Ameri and Al- } \\
\text { Zuhair (2019) }\end{array}$ \\
\hline
\end{tabular}




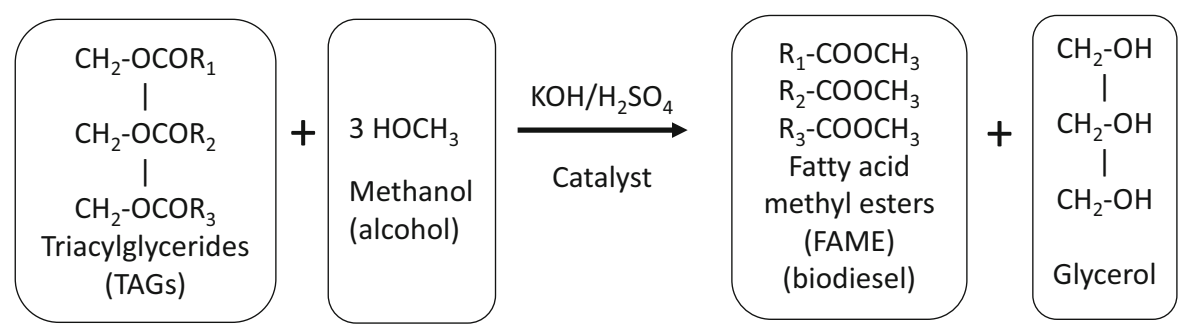

Fig. 2 Transesterification reaction for the conversion of TAG to fatty acid methyl esters

lipids, which helps in the easy extraction. Moreover, the use of a specific solvent, during cell disruption will help to prevent the degradation of targeted lipid and reduce the release of unwanted impurities in the crude extract which thereby simplifies the subsequent downstream process (Lee et al. 2020). This singlestep sequential extraction can also be used for the processing of wet biomass, which excludes the incorporation of the drying process and can reduce the cost in microalgal biorefinery. Moreover, the production of lipids for nutraceutical applications from microalgae depends on various factors. Integration of lipid extraction methods will have many benefits in terms of energy and chemical savings. Therefore, more research is needed to obtain high efficiency in the processing of wet microalgal biomass.

\section{Microalgae as a source of high-value metabolites and nutraceuticals}

Microalgae have many reported health benefits and have been used as a medicine from $1500 \mathrm{BC}$ (Moheimani and Borowitzka 2011). But more focus has been given recently to the use of microalgae as chemicals and nutraceuticals. High-value metabolites extracted from microalgae can act as nutritional supplements and can be used for food and feed applications. Consumption of such natural nutritional supplements can impart many health benefits to humans and animals. Microalgal biomass can replace fish meal and has more attracted to researchers as a potential renewable and ecofriendly source of nutrients in human diet and animal feed (Adarme-Vega et al. 2014; Udayan et al. 2017). These high-value bioactive metabolites have great potentials for the protection and therapy of many diseases (Udayan et al. 2018). Microalgae and macroalgae-derived compounds show different health-promoting activities (Lauritano et al. 2016).

Microalgae serve as a potential source for treating different health conditions and deficiency diseases occurred in populations worldwide. Microalgae can be used for the therapy of cancer, diabetes, hypertension, autoimmune diseases, neurodegenerative diseases and they can also be used for boosting immunity and maintenance of the proper brain and heart health by consuming a sufficient quantity of microalgae per day (Barkia et al. 2019; Kiran and Venkata Mohan 2021; Udayan et al. 2021). Microalgae have also been used as a moisturizing agent and sun protectants in cosmetics (Udayan et al. 2021).

Microalgae that are used in nutraceuticals production include Tetraselmis, Chlorella, Chaetoceros, Spirulina, Chlorella, Nannochloropsis, Cryptothecodinium, Dunaliella, etc. due to their potential of producing bioactive compounds. Additionally, these edible microalgae are a rich source of major micro and macro nutrients (Table 7). Owing to the potential health benefits of microalgae, the global market for microalgal biomass and high-value metabolites are getting more attention recently. In the present scenario, more funding has been attracted to screen highvalue metabolites from microalgae. The different bioactive metabolite was identified and extracted from microalgae and macroalgae, such as sulfated polysaccharides, carotenoids, beta carotene, omega 3 fatty acids, polyphenols, vitamins, and proteins.

It is very important to access the purity of nutraceuticals obtained from microalgae for nutritional purposes. Many of the microalgae are not known to produce any toxic products and their safety is well established (Udayan et al. 2021). In the recent years, quality of specific microalgal supplements are put in doubt because of the detection of cyanotoxins, and the coexistence of toxigenic microalgal species in the large scale cultivation systems. There are also 
Table 6 Sequential extraction of microalgal lipids

\begin{tabular}{|c|c|c|c|c|c|}
\hline $\begin{array}{l}\text { Cell-disruption } \\
\text { method }\end{array}$ & Species & Cell-disruption condition & $\begin{array}{l}\text { Extraction } \\
\text { method }\end{array}$ & $\begin{array}{l}\text { Production } \\
\text { efficiency } \\
\text { (mg/g cell) }\end{array}$ & Reference \\
\hline
\end{tabular}

\begin{tabular}{|c|c|}
\hline \multicolumn{2}{|l|}{ Mechanical method } \\
\hline \multicolumn{2}{|l|}{ Shear force } \\
\hline Bead milling & $\begin{array}{l}\text { Nannochloropsis } \\
\text { oculate }\end{array}$ \\
\hline \multicolumn{2}{|l|}{ High-pressure } \\
\hline \multirow[t]{2}{*}{$\begin{array}{l}\text { Homogenization at } \\
200 \text { to } 1000 \text { bar }\end{array}$} & $\begin{array}{l}\text { t-Butanol, } \\
\text { Ammonium } \\
\text { Sulfate }\end{array}$ \\
\hline & $\begin{array}{l}\text { Nannochloropsis } \\
\text { oculata }\end{array}$ \\
\hline $\begin{array}{l}\text { Hydrodynamic } \\
\text { cavitation }\end{array}$ & $\begin{array}{l}\text { Nannochloropsis } \\
\quad \text { salina }\end{array}$ \\
\hline \multicolumn{2}{|l|}{ Wave energy } \\
\hline $\begin{array}{l}\text { Ultra- } \\
\text { sonication }\end{array}$ & $\begin{array}{l}\text { Haematococcus } \\
\text { pluvialis }\end{array}$ \\
\hline Microwave & Chlorella sp. \\
\hline
\end{tabular}

\section{Electric force \\ Pulsed electric field
Chlorella vulgaris

Heat

$\begin{array}{lc}\text { Steam } & \begin{array}{c}\text { Nannochloropsis } \\ \text { oceanica }\end{array} \\ \begin{array}{l}\text { Hydrothermal } \\ \text { liquefaction }\end{array} & \begin{array}{c}\text { Nannochloropsis } \\ \text { oceanica }\end{array} \\ \text { Chemical method } & \\ \text { Acid } & \begin{array}{c}\text { Chlorella } \\ \text { vulgaris }\end{array} \\ & \\ \text { Osmotic shock } & \begin{array}{c}\text { Chlamydomonas } \\ \text { reinhardti }\end{array} \\ \text { Nanoparticle } & \begin{array}{c}\text { Chlorella } \\ \text { vulgaris }\end{array} \\ \text { Surfactant } & \begin{array}{c}\text { Chlorella } \\ \text { vulgaris }\end{array}\end{array}$

Biological method
Bead milling under 1750 bar pressure

$$
\text { homogenization }
$$

$400 \mathrm{mglipid} / \mathrm{g}$ cell

pH 6.0; homogenization at $125 \mathrm{MPa}$

Autoclave $(5 \mathrm{~kW})$; hydro cavitation

$(1.27 \mathrm{~kW})$; ultrasonication $(0.75 \mathrm{~kW})$

\section{Ultra-sonication in acetone}

Time-20 min; MAS-II microwave reaction system for synthesis/ extraction Methanol

Chlorella saccharophila

Mulchandani et al. (2015), Patel et al. (2018)

Petroleum Ether lipid/g cell (2016)

Hexane

$191.5 \mathrm{mg} \quad$ Lee and Han lipid/g cell (2015)

Hexane,
Isopropanol
Chloroform/
Methanol

$19.8 \mathrm{mg}$ lipid/g cell

Dong et al.

$0.095 \mathrm{mg}$ lipid/g cell

Cheng et al. (2015),

Alhattab

et al. (2019)

$25 \mathrm{kV} / \mathrm{cm}-100 \mu \mathrm{s}$; electrode distance Ethanol $0.25 \mathrm{~cm}$; electrode area $1.76 \mathrm{~cm}^{2}$; applied voltage $6.25 \mathrm{kV}$; applied current $55 \mathrm{~A}$

$0.1 \mathrm{~s}$ pressure release for $5 \mathrm{~min}$; steam at set pressure 1.0 to $2.1 \mathrm{MPa}$

Time-60 min; 89 bar; Temp-350 ${ }^{\circ} \mathrm{C}, \quad$ Dichloromethane

$1 \% \mathrm{H}_{2} \mathrm{SO}_{4}$ Temp- $120{ }^{\circ} \mathrm{C}$; Time$60 \mathrm{~min}$

$\mathrm{NaCl}$ or sorbitol $60 \mathrm{~g} / \mathrm{L}$

Time-96 h; $\mathrm{NiO}(<50 \mathrm{~nm})$, stirring at $80 \mathrm{rpm}$

Temp- $120{ }^{\circ} \mathrm{C}$, Time- $1 \mathrm{~h} ; 0.2 \%$ sodium dodecyl benzene sulfonate; $2 \% \mathrm{H}_{2} \mathrm{SO}_{4}$
Hexane, Methanol, Ethanol, Isopropanol

$\begin{array}{lr}0.4 \mathrm{mg} & \text { Luengo et al. } \\ \text { pigment/g } & \text { (2015), Sati } \\ \text { cell } & \text { et al. (2019) }\end{array}$

$763 \mathrm{mg} \quad$ Cheng et al. lipid/g cell (2015),

Onumaegbu et al. (2018)

$406 \mathrm{mg} \quad$ Yoo et al. biocrude/g (2015), Patel cell et al. (2018)

$381.6 \mathrm{mg} \quad$ Park et al. lipid/g cell (2014), Sati

Methanol, Chloroform/ Methanol

Chloroform/ Methanol Yoo et al. $\mathrm{lipid/g}$ cell (2012)

Chloroform/ $900 \mathrm{mg}$ Huang and lipid/g cell Kim (2016) lipid/g cell (2014), Alhattab et al. (2019) et al. (2019) $843.9 \mathrm{mg} \quad$ Park et al. 
Table 6 continued

\begin{tabular}{|c|c|c|c|c|c|}
\hline $\begin{array}{l}\text { Cell-disruption } \\
\text { method }\end{array}$ & Species & Cell-disruption condition & $\begin{array}{l}\text { Extraction } \\
\text { method }\end{array}$ & $\begin{array}{l}\text { Production } \\
\text { efficiency } \\
\text { (mg/g cell) }\end{array}$ & Reference \\
\hline Enzymatic lysis & $\begin{array}{l}\text { Nannochloropsis } \\
\text { oceanica }\end{array}$ & Lipase; cellulose; protease & Hexane & $\begin{array}{l}31.92 \mathrm{mg} \\
\text { lipid/g cell } \\
\text { in } \mathrm{g} / \mathrm{L} \\
\text { algal } \\
\text { culture }\end{array}$ & $\begin{array}{l}\text { Chen et al. } \\
\text { (2016a, b), } \\
\text { Bharte and } \\
\text { Desai (2018) }\end{array}$ \\
\hline $\begin{array}{l}\text { Algicidal } \\
\text { treatment }\end{array}$ & $\begin{array}{l}\text { Chlorella } \\
\text { vulgaris }\end{array}$ & $\begin{array}{l}\text { Time-3 days; Co-culture with } \\
\text { Flammeovirgayaeyamensis }\end{array}$ & Chloroform & $\begin{array}{l}218 \mathrm{mg} \\
\mathrm{lipid} / \mathrm{g} \text { cell }\end{array}$ & $\begin{array}{l}\text { Chen et al. } \\
\text { (2013) }\end{array}$ \\
\hline
\end{tabular}

Table 7 High value metabolites from microalgae and its health benefits

\begin{tabular}{|c|c|c|c|}
\hline $\begin{array}{l}\text { High value } \\
\text { metabolites }\end{array}$ & Microalgae & Health benefits & References \\
\hline \multicolumn{4}{|l|}{ Carotenoids } \\
\hline$\beta$ carotene & Dunaliella salina & $\begin{array}{l}\text { Food colorant, pro vitamin } \mathrm{A} \text {, anti- } \\
\text { oxidant, anti-inflammatory }\end{array}$ & $\begin{array}{l}\text { Sathasivam et al. (2019), Novoveská } \\
\text { et al. (2019) }\end{array}$ \\
\hline Astaxanthin & $\begin{array}{l}\text { C. zofingiensis, } H \text {. } \\
\text { pluvialis }\end{array}$ & Pigmenter, anti-oxidant, anti-inflammatory & $\begin{array}{l}\text { Novoveská et al. (2019), Dufosse } \\
\text { (2008) }\end{array}$ \\
\hline Zeaxanthin & C.ellipsoidea, D.salina & Food colorant, anti-oxidant & Raposo et al. (2015) \\
\hline Canthaxanthin & Chlorella sp. & $\begin{array}{l}\text { Food colorant, pigmenter in aquaculture } \\
\text { and poultry }\end{array}$ & Udayan et al. (2017) \\
\hline Lutein & $\begin{array}{l}\text { Scenedesmus sp. } \\
\text { Muriellopsis sp. } \\
\text { Chlorella } \mathrm{sp} .\end{array}$ & Anti-oxidant & Sathasivam et al. (2019) \\
\hline Phycobilins & $\begin{array}{l}\text { Cyanobacteria, } \\
\text { Rhodophyta }\end{array}$ & $\begin{array}{l}\text { Colorant in food and cosmetics, anti- } \\
\text { oxidant }\end{array}$ & Kannaujiya et al. (2020) \\
\hline \multicolumn{4}{|l|}{ Fatty acids } \\
\hline $\begin{array}{l}\text { Arachidonic acid } \\
\text { (ARA) }\end{array}$ & $\begin{array}{l}\text { P.purpureum, } P \text {. } \\
\text { cruentum, }\end{array}$ & $\begin{array}{l}\text { Improves growth and development of } \\
\text { neonates }\end{array}$ & (Udayan et al. 2017) \\
\hline $\begin{array}{l}\text { Eicosapentaenoic } \\
\text { acid (EPA) }\end{array}$ & $\begin{array}{l}\text { Nannochloropsis, } \\
\text { P.tricornutum, P. } \\
\text { cruentum }\end{array}$ & $\begin{array}{l}\text { Cognition, heart health, protection against } \\
\text { arthrosclerosis, anti-inflammatory }\end{array}$ & $\begin{array}{l}\text { Kannaujiya et al. (2020), Weill et al. } \\
\text { (2020) }\end{array}$ \\
\hline $\begin{array}{l}\text { Docosahexaenoic } \\
\text { acid (DHA) }\end{array}$ & $\begin{array}{l}\text { C.cohnii, Schizochytrium } \\
\text { sp., Ulkenia } \mathrm{sp.}\end{array}$ & $\begin{array}{l}\text { Brain and eye health, cardiovascular } \\
\text { benefits, nervous system development }\end{array}$ & $\begin{array}{l}\text { Udayan et al. (2017), Kannaujiya } \\
\text { et al. (2020), Weill et al. (2020) }\end{array}$ \\
\hline Peptides & $\begin{array}{l}\text { C.pyrenoidosa, N.oculata, } \\
\text { T.suecica, B.braunii }\end{array}$ & $\begin{array}{l}\text { Anti-hypertensive, anti-cancer, anti- } \\
\text { oxidant, anti-inflammatory }\end{array}$ & Udayan et al. (2017) \\
\hline $\begin{array}{l}\text { Sulfated } \\
\text { polysaccharides }\end{array}$ & $\begin{array}{c}\text { Porphyridium sp. } \\
\text { P.tricornutum, } \\
\text { C.pyrenoidosa, }\end{array}$ & $\begin{array}{l}\text { Antiviral, immunomodulatory, } \\
\text { antioxidant, anti-inflammatory }\end{array}$ & Udayan et al. (2017) \\
\hline Phenolics & $\begin{array}{l}\text { B.braunii, C.vulgaris, } \\
\text { Isochrysis sp. }\end{array}$ & Anti-oxidant & Udayan et al. (2017) \\
\hline
\end{tabular}


reports on the presence of toxic heavy metals such as arsenic, lead, aluminum due to the improper location of the microalgal cultivation ponds which can lead to the toxicity in microalgal supplements (Udayan et al. 2021). These toxic heavy metals can cause nausea, diarrhea, abdominal pain etc. after consumption. Therefore, it is indeed necessary that the nutritional products should be of high purity and the formulations should be investigated, but still the information in this regard is very limited.

Based on the nature of the substrate, microalgae can be autotrophic, mixotrophic, or heterotrophic. In the autotrophic or phototrophic mode of growth, microalgae utilize $\mathrm{CO}_{2}$, salts, and light energy its metabolism and primary growth. Microalgae can tolerate extreme stress conditions and even can be grown in nonpotable and sea water, without using potable water resources and arable land. High-value metabolites extracted by microalgae are easily digestible also (Udayan et al. 2017).

Polyunsaturated fatty acids

Polyunsaturated fatty acids (PUFAs) with 18 or more carbon are categorized as long-chain fatty acids categorized as $\omega-6$ and $\omega-3$ depending on the site of last unsaturation from the methyl end. Long-chain PUFAs found in fish and fish-derived oils are obtained from the microalgae in aquatic regions that are consumed and digested by fishes and therefore microalgae are rich in PUFAs. Eicosapentaenoic acid (EPA) and Docosahexaenoic acid (DHA) are important for brain function, memory, learning, and associated health benefits (Table 8). Several studies reported that omega 3 fatty acid consumption during pregnancy and breastfeeding will protect the infants from allergies (Table 8). Consumption of omega 3 fatty acids is also important for the maintenance of membrane fluidity and the development of the brain and retina. Improved problem-solving skills have been observed in infants whose mothers consumed omega 3 fatty acids in pregnant time (Judge et al. 2007). Children have also shown significantly higher vision and memory whose mothers have supplemented with EPA + DHA during pregnancy (Dunstan et al. 2008). It has been reported that omega 3 fatty acids can prevent the cytokine storm during COVID 19 pandemic and also helps to prevent difficulties in cardiovascular patients due to corona virus infection (Weill et al. 2020). EPA and DHA can lower triglycerides which help to lower the risk of developing cytokine storms (Mehta et al. 2020).

Many bacteria, fungi, microalgae, and plants are presently being explored as sources of EPA and DHA. In the aquatic ecosystem, microalgae are the initial EPA and DHA producers. They can grow in

Table 8 Potential beneficial effects of PUFAs and its physiological functions

\begin{tabular}{|c|c|c|c|}
\hline $\begin{array}{l}\text { Type } \\
\text { of } \\
\text { PUFA }\end{array}$ & Deficiency associated diseases & Physiological functions & \\
\hline ALA & $\begin{array}{l}\text { Cardiovascular diseases, cancer, coronary heart } \\
\text { disease, cardiac arrhythmias, myocardial } \\
\text { infarction }\end{array}$ & $\begin{array}{l}\text { Maintenance of serum cholesterol level, blood } \\
\text { pressure, decreased platelet aggregation, } \\
\text { adhesion of monocytes to blood vessels, vascular } \\
\text { dilation, inflammatory processes and immune } \\
\text { functions, neural integrity, learning and visual } \\
\text { abilities, development of retina and retinal } \\
\text { functions }\end{array}$ & $\begin{array}{l}\text { Udayan et al. } \\
\text { (2017) }\end{array}$ \\
\hline $\begin{array}{l}\text { EPA } \\
\text { and } \\
\text { DHA }\end{array}$ & $\begin{array}{l}\text { Coronary heart diseases, fatal myocardial } \\
\text { infarction, inflammatory diseases, bipolar } \\
\text { disorder, cognitive decline, aggression, age } \\
\text { related maculopathy }\end{array}$ & $\begin{array}{l}\text { Maintaining the production of Prostaglandin } \\
\text { metabolites and Thromboxane A2, inflammatory } \\
\text { processes and immunity, increased activity of } \\
\text { Rod photoreceptor, visual acuity and neural } \\
\text { function, maintenance of serum cholesterol, } \\
\text { development of brain and retina (infants) }\end{array}$ & $\begin{array}{l}\text { Kannaujiya et al. } \\
\text { (2020), Weill } \\
\text { et al. (2020) }\end{array}$ \\
\hline LA & Cardiovascular diseases & $\begin{array}{l}\text { Maintenance of cholesterol, lipid levels, platelet } \\
\text { aggregation, maintenance of blood pressure, } \\
\text { inflammatory processes and immune responses }\end{array}$ & $\begin{array}{l}\text { Udayan et al. } \\
\text { (2017) }\end{array}$ \\
\hline
\end{tabular}


autotrophic, mixotrophic, and heterotrophic culture conditions naturally at a fast rate with the production of high long-chain $\omega-3$ fatty acids. EPA and DHA are among the major commercially produced PUFAs and microalgae are known to accumulate these in large quantities. Considering the commercial interest regarding EPA and DHA production, strategies for the screening of high omega-3 fatty acid yielding microalgal strains, genetic manipulation, process optimization, and innovation of efficient cultivation systems have been explored. Ren and colleagues studied the effects of air sparging rates on omega 3 fatty acid production by Schizochytrium sp. Fed-batch fermentation in a bioreactor with $1500 \mathrm{~L}$ capacity was carried out with varying aeration rates. This approach resulted in high biomass, lipid production, and DHA content at $71 \mathrm{~g} / \mathrm{L}, 35.75 \mathrm{~g} / \mathrm{L}$, and $48.95 \%$, respectively with high DHA productivity (Ren et al. 2010). In another strategy, the production of DHA was investigated through a double stage culturing process which resulted in $154 \mathrm{mg} \mathrm{DHA} / \mathrm{L} / \mathrm{ha}$ by the use of Aurantiochytrium limacinum SR21 (Rosa et al. 2010). This study was based on the understanding that microalgae growth and accumulation of different value-added metabolites in cells require different nutritional conditions. Udayan et al. 2020 reported that the addition of Salicylic acid, a major stress phytohormone increased the EPA production in N.oceanica up to 1.5 fold compared to control (Udayan et al. 2020). The addition of Kinetin and IAA to N.oceanica CASA CC2O1 increased the percentage of omega 3 fatty acid fourfold and twofold in comparison with the control (Udayan et al. 2018).

Factors affecting the synthesis of omega 3 fatty acids

Microalgal metabolite induction can be achieved by changing the growth conditions or through the modification of nutrient composition. Increased accumulation of starch or lipids can be correlated with microalgal survivor mechanisms in response to different stress conditions such as temperature, $\mathrm{pH}$, UV radiation, or nutrient limitation (Udayan et al. 2017). During stress conditions or nutrient limitation, microalgal growth will shift towards the accumulation of high-energy-rich compounds like lipids and unsaturated fatty acids (Udayan et al. 2020). Omega 3 fatty acid production can be increased by modification of nutrient conditions and environmental stresses like light intensity, temperature, $\mathrm{pH}$, and $\mathrm{UV}$ radiation.

\section{Light intensity}

Light intensity is considered as one of the most important parameters for microalgal growth and biomass production. Apart from growth aspects, sufficient light intensity is required for photosynthesis to generate ATP and NADPH for the production of metabolites necessary for growth (Niccolai et al. 2019). Light intensity increases the growth and biomass production of microalgae up to a specific point after that it leads to photo inhibition. Insufficient light intensity decreases the growth of microalgae. Stress conditions with low or high light intensity lead to a decrease in biomass production (Sun et al. 2018). Lipid and fatty acid production also depend on the level of light intensity (Sun et al. 2018). But the production of polyunsaturated fatty acids and lipids on different light intensities are species-specific. In some species, the low light intensity increased the production of EPA while high light intensities induced the production of DHA. PUFA levels were found to be increased at low light intensities to adapt to the low light stress by increasing PUFA synthesis (Sun et al. 2018).

\section{Temperature}

The temperature has a major role in growth, lipid accumulation, and fatty acid production in microalgae. During low temperatures, PUFA content was found to be increased to overcome the low-temperature stress and maintain the cell membrane fluidity. Low-temperature treatments resulted in higher EPA and PUFA production in microalgae, with a significant reduction in growth rate and biomass production (Aussant et al. 2018). However, there is a variation in temperature required for growth from species to species with no overall consistent correlation between temperature and the number of double bonds in fatty acids. Therefore, the highest overall production yields of PUFAs and omega 3 fatty acids cannot be achieved at lower temperatures. 
Nutrient stress

Nitrogen, phosphorous, and sulfur are very essential nutrients for the growth of microalgal cells. Yang et al. (2018) reported that nitrogen deficiency and phosphorous deficiency will inhibit microalgal growth and cell division (Yang et al. 2018). Micronutrients like $\mathrm{Cu}$ and $\mathrm{Zn}$ which are required in small amounts have a strong impact on microalgal growth because they mediate and control many enzymatic activities in the cell (Yang et al. 2018). Lack of nitrogen source in the culture media affects microalgal growth and other biosynthetic pathways and the microalgal metabolism will shift towards lipid accumulation (Conde et al. 2021). Nitrogen depletion has resulted in the highest EPA productivity in $N$. oceanica IMET 1 . Nitrogen starvation increased EPA and Triacyl glycerol (TAG) production in $N$. gaditana cultivated for 14 days (Janssen et al. 2019).

\section{$U V$ radiation}

UV radiation causes damaging effects on different enzymatic and biochemical pathways including the fatty acid synthesis of microalgae (Udayan et al. 2017). Numerous studies have been conducted to analyze the effect of UV radiation in microalgae; however, the results were often contradictory. Exposure of microalgae to UV-B radiation increases the levels of saturated fatty acids (SFAs) and monounsaturated fatty acids (MUFAs) with a significant decrease in polyunsaturated fatty acids (PUFAs) (Oliver et al. 2020). EPA content in P. tricornutum increased up to 19.84\% when exposed to UV light (Liang et al. 2006). Stress induction due to exposure to UV radiation causes the formation of antioxidants in microalgae which could be the reason for enhanced PUFA synthesis.

\section{Reactive oxygen species (ROS) and antioxidants}

Alleviation of Reactive oxygen species (ROS) generation and lipid peroxidation can also cause an increase in omega 3 fatty acid production in microalgae. Zhang et al. (2018) reported that over expression of the superoxide dismutase (SOD) gene in Schizochytrium $s p$. has significantly increased the PUFA content by $32.9 \%$ (Zhang et al. 2018). The addition of antioxidants has also been used to increase omega 3 fatty acid and PUFA synthesis in microalgae. For example, DHA productivity in Schizochytrium sp. and Crypthecodinium cohnii has increased after treatment with antioxidants ascorbic acid and sesamol (Liu et al. 2015).

\section{Genetic engineering}

Currently, the biosynthesis of fatty acids in microalgae is not extensively studied and most of the information has been acquired from studies on plant metabolism. Researchers have been made efforts to produce recombinant sources of omega 3 fatty acids in different systems, but the success rate was very less (Table 9). Recombinant Canola seeds were produced by over-expressing the $\Delta 15$ desaturase from Brassica napus to synthesize omega 3 fatty acids (Oliver et al. 2020; Sirohi et al. 2021a). In the future, it could be possible to increase the production of omega 3 fatty acids in microalgae by regulating the expression of enzymes involved in the fatty acid synthesis. Another possible mechanism to increase productivity can be the inhibition of PUFA degradation in peroxisomes during $\beta$-oxidation. However, the exact mechanism of PUFA synthesis in microalgae is still at the early stages of research.

\section{Carotenoids}

Most photosynthetic organisms contain carotenoids which are red, yellow, or orange pigments, insoluble in water. Microalgal carotenoids have gained increasing global attention due to their unique properties, especially health-associated benefits and new avenues for their production (Novoveská et al. 2019). They seem penetrating well in the global carotenoids market which was US\$ 1.24 billion in 2016 and was estimated to reach 1.53 billion in 2021 (Ambati et al. 2019). Astaxanthin, lutein, lycopene, and canthaxanthin are the major carotenoids present in the chloroplast of most algae and prevent photo-oxidative damage caused due to high-intensity light exposure. There are many methods like continuous, batch, fed-batch using different reactors such as closed systems (photobioreactors), open pond systems. Among all the technologies photobioreactors are the most economic method of carotenoid production from microalgae perhaps due to the cost of microalgae production. Table 10 represents the commercial methods and 
Table 9 Genetic engineering strategies for enhanced lipid and fatty acid accumulation

\begin{tabular}{|c|c|c|c|c|}
\hline Microalgae & $\begin{array}{l}\text { Targeted } \\
\text { genes }\end{array}$ & Strategy & Effect on lipid accumulation & References \\
\hline $\begin{array}{l}\text { Chlamydomonas } \\
\text { reinhardtii }\end{array}$ & $A C S 2$ & Overexpression & $\begin{array}{l}\text { 2.4 Fold increase in Triacyl glycerol content under } \\
\text { nitrogen starvation conditions }\end{array}$ & $\begin{array}{l}\text { Rengel et al. } \\
\text { (2018) }\end{array}$ \\
\hline $\begin{array}{l}\text { Nannochloropsis } \\
\text { oceanica }\end{array}$ & NoMCAT & Overexpression & Neutral lipid content was increased to $31 \%$ & $\begin{array}{l}\text { Chen et al. } \\
\text { (2017) }\end{array}$ \\
\hline Schizochytrium sp & $M A T$ & Overexpression & PUFA content was increased to $24.5 \%$ & $\begin{array}{l}\text { Li et al. } \\
(2018)\end{array}$ \\
\hline $\begin{array}{l}\text { Chlamydomonas } \\
\text { reinhardtii }\end{array}$ & DtTE & $\begin{array}{l}\text { Heterologous } \\
\text { expression }\end{array}$ & $69 \%$ Increase in neutral lipids & $\begin{array}{l}\text { Tan and Lee } \\
\text { (2017) }\end{array}$ \\
\hline $\begin{array}{l}\text { Scenedesmus } \\
\text { quatricauda }\end{array}$ & $A C C 1$ & $\begin{array}{l}\text { Heterologous } \\
\text { expression }\end{array}$ & 1.6 Fold increase in lipid content & $\begin{array}{l}\text { Gomma et al. } \\
\text { (2015) }\end{array}$ \\
\hline $\begin{array}{l}\text { Cyanidioschyzon } \\
\text { merolae }\end{array}$ & $\begin{array}{l}\text { Acyl-ACP- } \\
\text { reductase }\end{array}$ & $\begin{array}{l}\text { Heterologous } \\
\text { expression }\end{array}$ & Threefold increase in Triacyl glycerol content & $\begin{array}{l}\text { Sumiya et al. } \\
\text { (2015) }\end{array}$ \\
\hline
\end{tabular}

factors affecting the carotenoid production from microalgae.

\section{Astaxanthin}

Astaxanthin can be commercially produced using microalgae as a feedstock and its production from microalgae is economic and well established on a large scale (Novoveská et al. 2019). Astaxanthin is known for its strong antioxidant activity. Astaxanthin shows antioxidant property that is 10 times of $\beta$-carotene and above 500 times that of $\alpha$-tocopherol (Dufosse 2008). Astaxanthin is used for pigmentation in the aquaculture industry which is approved by US FDA in 1987 and further in 1999 (Table 2). Being a strong antioxidant, astaxanthin is commercially used in food, nutraceuticals, and cosmetics and has also displayed positive effects on the therapy of inflammatory diseases, diseases of heart, liver, nervous system, cancers, metabolic syndrome, diabetes, and gastrointestinal diseases. Various microalgae such as Botryococcus braunii, Chlamydocapsa sp., Chlamydocapsa nivalis, Chlorella zofingiensis, Chlorococcum sp., Haematococcus pluvialis are capable to produce astaxanthin. Among these species, H. pluvialis is accepted as one of the best producers of astaxanthin because of its nature to accumulate enough amounts in harsh conditions (Oslan et al. 2021). Li et al (2020) produced astaxanthin using $H$. pluvialis by a cell transformation strategy and found that $38.02 \mathrm{mg} / \mathrm{g}$ of astaxanthin can accumulate which is 2.1 times higher as compared to the control (Li et al. 2020). Molino and his group were able to accumulate $18.5 \mathrm{mg} / \mathrm{g}$ dry weight astaxanthin in $H$. pluvialis at a bench-scale reactor (Molino et al. 2018).

\section{Lycopene}

Lycopene is used as a natural colorant and food additive. Its industrial production is usually done through microbial sources, typically by Escherichia coli. However, there are other microorganisms such as yeast (e.g., Candida utilis) also which have been reported for their production. Genetic and metabolic engineering tools have widely been used to modulate microbial strains for improved production of desired flavonoids (Lee and Schmidt-Dannert 2002; Rathod et al. 2020).

Lycopene production has been evaluated by several microalgal cultures such as Chlorella vulgaris, Nephroselmis sp, Dunaliella salina, etc. (Coulombier et al. 2020; Mazzucchi et al. 2020; Mtaki et al. 2020). Coulombier et al. (2020) conducted the experiments under nitrogen starvation conditions in 10L photobioreactors for 28 days and observed increased lutein content (5.22-7.97 $\mathrm{mg} \mathrm{g}^{-1}$ DW) under nitrogen replete conditions. Similarly Mazzucchi et al. (2020), cultivated D. salina in Algem photobioreactors under red and blue light for $48 \mathrm{~h}$ for beta carotene production. Mtaki et al. (2020) used a low-cost media in which a strain of Chlorella vulgaris was cultivated and assessed for its antioxidant and free radical 


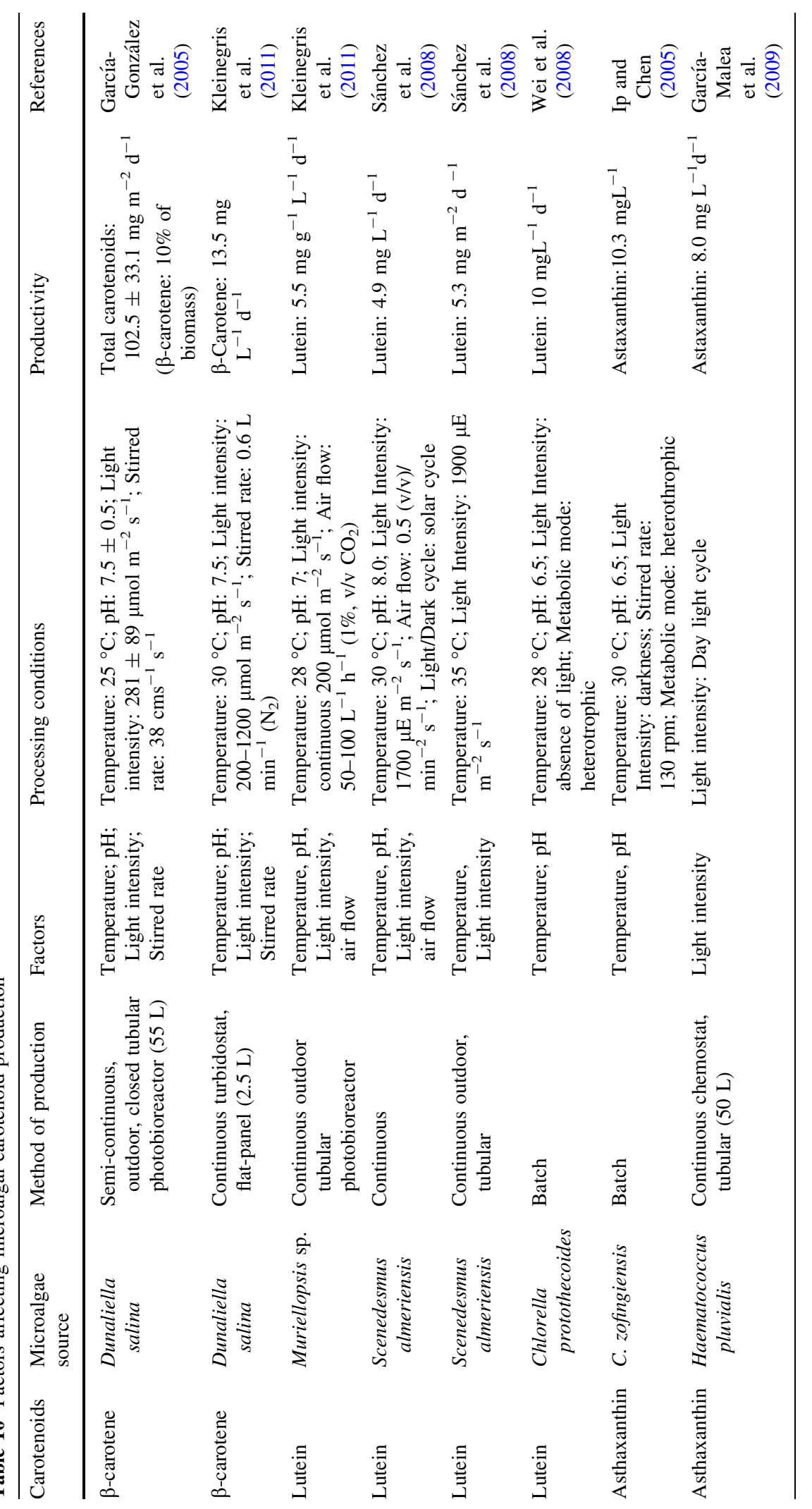


scavenging capacity. It was interesting to note that the spectrum of different product formations was quite related to the nature of the substrate. For example, when microalgae were cultivated in a synthetic medium, namely, Bold basal medium (BBM), the Chlorella vulgaris cells produced lycopene in the highest quantity, compared to a compost medium or aquaculture wastewater supplemented with NPK. Compost medium resulted in the highest production of phenolics while aquaculture medium produced higher flavanoid and $\beta$-carotene compared to other media. Therefore, wastewater could be employed for the cultivation of microalgae to produce carotenoids such as lycopene.

Considering the significance of microalgae in aquatic food chains and their capacity to fix carbon and to produce together another ecological role, microalgae-based biorefinery for the production of carotenoids and flavonoids seems very attractive with potential for commercial-scale exploitation. Also, considering that currently only about 3000 microalgal species have been studied and available in culture collections (from the about 44,000 known species) (Guiry 2012), there is huge potential and perspectives for their exploitation for the production of value-added products. What's more- out of all the known species, apparently only 40 are being commercially used for different applications (Day et al. 2012), showing huge opportunities.

\section{Lutein}

Lutein is a primary xanthophyll, a potent antioxidant and among the two carotenoids present in the retina of the human eye and lens (Sun et al. 2015). Lutein protects the DNA, proteins, and unsaturated lipids from oxidation and also provides a protective effect against cataracts. Numerous microalgal species, particularly Chlorella, can produce lutein and have been considered as an excellent alternative to plant-based lutein, which is season-dependent. Various strategies have been devised to make the process of lutein recovery from microalgae efficient. For instance, Chen et al. (2016a, b) reported that the use of high pressure followed by extraction with tetrahydrofuran could result in $99.5 \%$ lutein recovery from $C$. sorokiniana (Chen et al. 2016a, b). Molino et al. (2020) explored the effect of $\mathrm{CO}_{2}$ concentration on the yield of lutein from $S$. almeriensis and established that lutein production can be enhanced at high $\mathrm{CO}_{2}$ concentrations $(\sim 3 \% \mathrm{v} / \mathrm{v})$ due to higher chlorophyll accumulation (Molino et al. 2020). Ma et al. (2020) reported a two-stage bioprocess for enhanced lutein production from Chlorella sorokiniana (Ma et al. 2020). They investigated the effect of different temperatures, light intensities, and operating conditions on lutein production. They observed higher lutein production at $33{ }^{\circ} \mathrm{C}$, low light intensity $\left(150 \mu \mathrm{mol} / \mathrm{m}^{2} / \mathrm{s}\right)$, and with gradient fed-batch conditions. Barathan et al. (2021) investigated the effect of beijerinck solution (BS), phosphate solution (PS), and hunter trace (HT) on lutein production using Chlorella pyrenoidosa (Barathan et al. 2021). It was found that an increase in HT concentration always increased lutein recovery.

\section{Canthaxanthin}

Canthaxanthin, also known as $\beta, \beta$-carotene-4,4'dione, is a red/orange colored di-ketocarotenoid. Canthaxanthin shows numerous health-promoting attributes including anti-cancer, antioxidant, antiinflammatory, and immunomodulatory activities (Rebelo et al. 2020; Lafarga et al. 2021). It has been widely reported that Canthaxanthin could be better accumulated in microalgae under a stressful environment that could include osmotic stress, thermal stress, oxidative stress, nitrate starvation, and intense solar radiation among others (Lafarga et al. 2021). Canthaxanthin can be extracted from microalgae using different liquid chromatographic techniques specifically, high speed counter current chromatography. Chromochloris zofingiensis has been reported to be a valuable source of canthaxanthin along with astaxanthin and adonixanthin (Minyuk et al. 2020).

\section{Phycobilins/phycobiliproteins}

Phycobilins are linear tetrapyrroles similar in structure to chlorophylls. Phycobiliproteins are water-soluble substances formed as a result of covalent bonding between phycobilins and polypeptides. Depending upon their absorption spectra, phycobiliproteins are classified as high-energy phycoerythrins (PEs) or phycoerythrocyanins (PECs) (480-580 nm), intermediate-energy phycocyanins (PCs) (600-640 nm), and low-energy allophycocyanins (APCs) (620-660 nm). Phycobiliproteins are used as a potential fluorescent 
labeling agent. This fluorescent behavior of phycobiliproteins can be utilized in different research activities (Udayan et al. 2017). Colored variants of phycobiliproteins are produced by many species of microalgae in large amounts. Differently colored phycobiliproteins are present in cyanobacteria which is beneficial to the health of humans (Kannaujiya et al. 2020). But the biosynthetic mechanism of phycobiliproteins in cyanobacteria is still unclear. Phycobiliproteins have a significant role in the food, nutraceutical, and pharmaceutical industries. It can be used as a coloring agent, fluorescence dye, anticancer, anti-inflammatory, antiviral, antibacterial, and antioxidative medicines (Wu et al. 2016). Currently, researchers are focused on developing technologies such as photodynamic therapy, disease diagnosis, solar cell, and disease treatment using phycobiliproteins (Wan et al. 2017). The potential $\mathrm{f}$ phycobiliproteins for commercial uses can create more economic growth for the microalgal industry as well as for human welfare.

\section{Carbohydrates}

Carbohydrates are mainly present in cell membranes and vacuoles of microalgae and they can also be secreted to the exterior of the cell as exopolysaccharides (Wells et al. 2017). Microalgae can accumulate higher content of carbohydrates under different cultivation conditions (Mayers et al. 2018). Microalgae such as Chlorella, Chlamydomonas, or Scenedesmus can accumulate high carbohydrate content of about
$12-32 \%$ on a dry biomass basis (Uyaguari-Diaz et al. 2016; Mayers et al. 2018). Carbohydrates possess great significance as additives in the food industry and production of biofuels like biogas or ethanol (Markou et al. 2012; Lam et al. 2014). Nitrogen-depleted condition promotes carbohydrate accumulation (57\%) in Desmodesmus sp. (Rizza et al. 2017). Microalgal ethanol yield is influenced by the type of species as well as process conditions and production higher than that by conventional feedstocks like corn or sugar beet has been reported. Chlorococcum sp. provided the highest reported ethanol yield with $0.52 \mathrm{~g} / \mathrm{g}$ using acid hydrolysis which is much higher as compared to bioethanol fermentation from wheat yielding $0.23 \mathrm{~g} / \mathrm{g}$ (Lee et al. 2011). The comparative analysis demonstrated the ethanol production potential of microalgae. For bioethanol production, carbohydrates are converted into fermentable sugars, and hydrolysis of carbohydrates of microalgal biomass through acid or alkaline pretreatment can be a decently effective method for doing so. There are many challenges associated with the development of different products using microalgal-derived carbohydrates as the main source (Fig. 3). The major difficulty occurs during the extraction and downstream processing but is easier in comparison with the plant-derived product because of the absence of lignification of the cell wall (Wells et al. 2017).

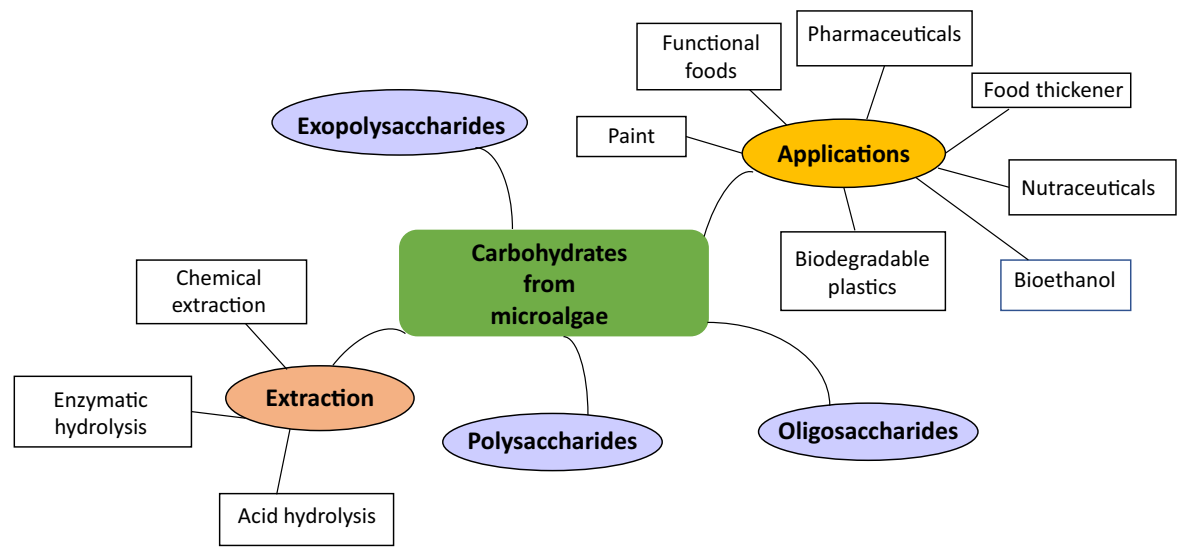

Fig. 3 Applications of microalgal carbohydrates and extraction methods 


\section{Proteins}

A substantial market for proteins is present around the world due to their increasing demand in industries especially related to food and pharmaceuticals. More than $50 \%$ of microalgae biomass is constituted of proteins, creating an opportunity for biorefineries to use this high protein content into value-added products. The high protein content of microalgae such as Spirulina (60\% protein on a dry basis) and Chlorella vulgaris (51-58\% dry basis) are being commercialized presently as food supplements (Hariskos and Posten 2014; Trivedi et al. 2015). However, commercial expansion of the use of microalgae protein is often obstructed by the fact that proteins of many microalgae species are biologically indigestible, a drawback attributed to their hard cell walls (Ursu et al. 2014). Chemical hydrolysis methods are mainly used to recover proteins; digestion of biomass with sodium hydroxide at higher temperatures usually provides a recovery efficiency of around $81 \%$ (Asiedu et al. 2018). The recovery efficiency varies with microalgae species and also depends on degradation resistance. The selection of extraction and purification technique depends upon the desired form in which protein product is required i.e. concentrate, isolate, or hydrolysate, and accordingly, the type of hydrolyzing agent, $\mathrm{pH}$, and time are also varied (Soto-Sierra et al. 2018). Sonication and beat milling are among other common disruption methods used for protein recovery with beat milling being preferred at commercial scale due to the lower energy input required.

\section{Challenges and future perspectives}

Given the current corona virus pandemic situation, more nutrient and health-promoting food are required to meet the dietary requirements of the global population. In this regard, microalgal biorefinery has emerged as a sustainable solution for the production of high-value metabolites and nutraceuticals. The major technological challenges associated with microalgal high-value metabolite production are low biomass and product yield and the high cost involved in the cultivation and downstream processing of biomass. Hence it is indeed necessary to develop strategies for an efficient biorefinery by improving the cultivation process and energy-efficient downstream processing of metabolites. Economically feasible lipid and nutraceutical production can be achieved by integration of upstream and downstream processing to reduce the energy and cost associated with the process. Consequently, cost and energy analysis should also be performed to understand the economic feasibility of the developed microalgal biorefinery. The prospects should also involve the development of metabolically engineered strains that are capable of high biomass and secondary metabolite production. Metabolic engineering together with bioprocess strategies will be effective for developing genetically modified microalgal strains with high lipid and biomass production for food and nutraceutical applications.

Another major problem associated is downstream processing. Regardless of how much amount of biomass is produced it is very important to develop an integrated biorefinery that permits the extraction of a maximum number of products and by-products, together with the minimum amount of residual or waste generation and maximum return on the investment for downstream processing (Fabris et al. 2020). There are several approaches to achieve this goal. Industry 4.0 is a new manufacturing approach based on the principle of the machine to machine communication technology which is also referred to as "the Internet of Things" (IoT) which involves sensors, automation, and machine learning to develop a selfadapting manufacturing process for understanding the realtime changes (Kumar et al. 2019). This approach can be integrated into microalgal biorefinery for automation of cultivation and harvesting systems to decrease the cost of operation and also to monitor the microalgal growth and productivity in real-time (Whitmore et al. 2014). The basic idea of Industry 4.0 helps to build a simulation, which could be used to predict the future microalgal lipid and metabolites yield and to adjust parameters to reduce the waste generation. Phenomics can be considered as another approach that can make algal biorefinery efficient. But microalgal Phenomics is still in the early development stages, but it has an important role in the use of microalgae in agriculture for food security, nutraceuticals, pharmaceuticals, bioremediation, and carbon sequestration (Fabris et al. 2020). Synthetic biology approaches can be also used for the development of an efficient biorefinery system which includes the application of engineering principles for the rational design of living organisms (Fabris et al. 2020). Application of 
synthetic biology to microalgae together with new genetic models with the advantages of a photosynthetic host to generate novel production strains can be used for future nutraceutical and pharmaceutical applications.

\section{Conclusions}

Overexploitation of fossil fuels is creating serious environmental problems and ecological imbalances. During the present pandemic conditions, finding an effective solution for the production of edible oils, other immune boosters, health-promoting substances is indeed necessary. To solve the drawbacks to develop an efficient microalgal biorefinery system, it is important to develop efficient process intensification strategies and downstream processing technologies. The present study addresses the strategies for enhanced production of lipids and their nutraceutical applications from microalgae. We also addressed the current challenges in largescale microalgal biorefinery and its solutions in future perspectives. Technoeconomically feasible nutraceutical and pharmaceutical production from microalgae can be achieved by integrating the upstream and downstream processes which will help to balance the energy and production cost.

\section{Declarations}

Conflict of interest The authors declare that they have no conflict of interest.

\section{References}

Abomohra AEF, El-Naggar AH, Alaswad SO et al (2020) Enhancement of biodiesel yield from a halophilic green microalga isolated under extreme hypersaline conditions through stepwise salinity adaptation strategy. Bioresource Technol 310:123462

Abreu AP, Fernandes B, Vicente AA et al (2012) Mixotrophic cultivation of Chlorella vulgaris using industrial dairy waste as organic carbon source. Bioresour Technol. https:// doi.org/10.1016/j.biortech.2012.05.055

Adarme-Vega TC, Thomas-Hall SR, Schenk PM (2014) Towards sustainable sources for omega-3 fatty acids production. Curr Opin Biotechnol 26:14-18

Al-Ameri M, Al-Zuhair S (2019) Using switchable solvents for enhanced, simultaneous microalgae oil extraction-reaction for biodiesel production. Biochem Eng J 141:217-224
Alhattab M, Kermanshahi-Pour A, Brooks MSL (2019) Microalgae disruption techniques for product recovery: influence of cell wall composition. J Appl Phycol 31(1):61-88

Ambati RR, Gogisetty D, Aswathanarayana RG et al (2019) Industrial potential of carotenoid pigments from microalgae: current trends and future prospects. Crit Rev Food Sci Nutr 59:1880-1902

Aratboni HA, Rafiei N, Garcia-Granados R et al (2019) Biomass and lipid induction strategies in microalgae for biofuel production and other applications. Microb Cell Fact 18:1-17

Artamonova EY, Vasskog T, Eilertsen HC (2017) Lipid content and fatty acid composition of Porosira glacialis and Attheya longicornis in response to carbon dioxide $(\mathrm{CO} 2)$ aeration. PLoS ONE 12(5):e0177703

Asiedu A, Ben S, Resurreccion E, Kumar S (2018) Technoeconomic analysis of protein concentrate produced by flash hydrolysis of microalgae. Environ Prog Sustain Energy. https://doi.org/10.1002/ep.12722

Aussant J, Guihéneuf F, Stengel DB (2018) Impact of temperature on fatty acid composition and nutritional value in eight species of microalgae. Appl Microbiol Biotechnol 102:5279-5297

Awasthi MK, Ferreira JA, Sirohi R et al (2021) A critical review on the development stage of biorefinery systems towards the management of apple processing-derived waste. Renew Sustain Energy Rev 143:110972

Aziz MMA, Kassim KA, Shokravi Z et al (2020) Two-stage cultivation strategy for simultaneous increases in growth rate and lipid content of microalgae: a review. Renew Sustain Energ Rev 119:109621

Babu AG, Wu X, Kabra AN, Kim DP (2017) Cultivation of an indigenous Chlorella sorokiniana with phytohormones for biomass and lipid production under N-limitation. Algal Res 23:178-185

Barathan BP, Elsawah AM, Liyuan Z, Poon K (2021) Modeling and optimization of the effect of abiotic stressors on the productivity of the biomass, chlorophyll and lutein in microalgae Chlorella pyrenoidosa. J Agric Food Res 5:100163

Barkia I, Saari N, Manning SR (2019) Microalgae for highvalue products towards human health and nutrition. Mar Drugs 17:304

Baumgardt FJL, Zandoná Filho A, Brandalize MV et al (2016) Lipid content and fatty acid profile of Nannochloropsis oculata before and after extraction with conventional solvents and/or compressed fluids. J Supercrit Fluids 108:89-95

Bharte S, Desai K (2021) Techniques for harvesting, cell disruption and lipid extraction of microalgae for biofuel production. Biofuels 12:285-305

Bhatia SK, Mehariya S, Bhatia RK et al (2021) Wastewater based microalgal biorefinery for bioenergy production: progress and challenges. Sci Total Environ 751:141599

Breuer G, Lamers PP, Martens DE et al (2013) Effect of light intensity, $\mathrm{pH}$, and temperature on triacylglycerol (TAG) accumulation induced by nitrogen starvation in Scenedesmus obliquus. Bioresour Technol. https://doi.org/10. 1016/j.biortech.2013.05.105 
Callejón MJJ, Medina AR, Moreno PAG et al (2020) Simultaneous extraction and fractionation of lipids from the microalga Nannochloropsis sp. for the production of EPArich polar lipid concentrates. J Appl Phycol 32:1-12

Cheah WY, Show PL, Chang JS et al (2015) Biosequestration of atmospheric $\mathrm{CO}_{2}$ and flue gas-containing $\mathrm{CO}_{2}$ by microalgae. Bioresour Technol 184:190-201

Chen CY, Yeh KL, Aisyah R et al (2011) Cultivation, photobioreactor design and harvesting of microalgae for biodiesel production: a critical review. Bioresour Technol. https://doi.org/10.1016/j.biortech.2010.06.159

Chen CY, Der BM, Chang JS (2013) Improving microalgal oil collecting efficiency by pretreating the microalgal cell wall with destructive bacteria. Biochem Eng J 81:10-176

Chen CY, Hsieh C, Lee D-J et al (2016a) Production, extraction and stabilization of lutein from microalga Chlorella sorokiniana MB-1. Bioresour Technol 200:500-505

Chen L, Li R, Ren X, Liu T (2016b) Improved aqueous extraction of microalgal lipid by combined enzymatic and thermal lysis from wet biomass of Nannochloropsis oceanica. Bioresour Technol 214:138-143

Chen J, Liu W, Hu D et al (2017) Identification of a malonyl CoA-acyl carrier protein transacylase and its regulatory role in fatty acid biosynthesis in oleaginous microalga Nannochloropsis oceanica. Biotechnol Appl Biochem 64:620-626

Cheng J, Huang R, Li T, Zhou J, Cen K (2015) Physicochemical characterization of wet microalgal cells disrupted with instant catapult steam explosion for lipid extraction. Bioresour Technol 191:66-72

Chia SR, Ong HC, Chew KW et al (2018) Sustainable approaches for algae utilisation in bioenergy production. Renew Energy 129:838-852

Chowdury KH, Nahar N, Deb UK (2020) The growth factors involved in microalgae cultivation for biofuel production: a Review. Comput Water Energy Environ Eng 9:185-215

Chu WL (2017) Strategies to enhance production of microalgal biomass and lipids for biofuel feedstock. Eur J Phycol 52:419-437

Conde TA, Neves BF, Couto D et al (2021) Microalgae as sustainable bio-factories of healthy lipids: evaluating fatty acid content and antioxidant activity. Mar Drugs 19:357

Costa JAV, de Freitas BCB, Lisboa CR et al (2019) Microalgal biorefinery from $\mathrm{CO}_{2}$ and the effects under the Blue Economy. Renew Sustain Energy Rev 99:58-65

Coulombier N, Nicolau E, Le Déan L et al (2020) Effects of nitrogen availability on the antioxidant activity and carotenoid content of the microalgae Nephroselmis sp. Mar Drugs 18:453

Cuellar-Bermudez SP, Romero-Ogawa MA, Vannela R et al (2015) Effects of light intensity and carbon dioxide on lipids and fatty acids produced by Synechocystis sp. PCC6803 during continuous flow. Algal Res 12:10-16

Day JG, Slocombe SP, Stanley MS (2012) Overcoming biological constraints to enable the exploitation of microalgae for biofuels. Bioresour Technol 109:245-251

Deshmukh S, Kumar R, Bala K (2019) Microalgae biodiesel: a review on oil extraction, fatty acid composition, properties and effect on engine performance and emissions. Fuel Process Technol 191:232-247
Dong T, Knoshaug EP, Pienkos PT, Laurens LML (2016) Lipid recovery from wet oleaginous microbial biomass for biofuel production: a critical review. Appl Energy 177:879-895

Dorni C, Sharma P, Saikia G, Longvah T (2018) Fatty acid profile of edible oils and fats consumed in India. Food Chem 238:9-15

Dufosse L (2008) Pigments from microalgae and microorganisms: sources of food colorants, pp 399-426

Dunstan JA, Simmer K, Dixon G, Prescott SL (2008) Cognitive assessment of children at age $2 \frac{1}{2}$ years after maternal fish oil supplementation in pregnancy: a randomised controlled trial. Arch Dis Childhood-Fetal Neonatal Ed 93:F45-F50

Ebrahimian E, Seyyedi MS, Bybordi A, Damalas CA (2019) Seed yield and oil quality of sunflower, safflower, and sesame under different levels of irrigation water availability. Agric Water Manag 218:149-157

Enamala MK, Enamala S, Chavali M et al (2018) Production of biofuels from microalgae-a review on cultivation, harvesting, lipid extraction, and numerous applications of microalgae. Renew Sustain Energy Rev 94:49-68

Energy I, Change C (2017) World energy outlook special report (2015). IEA Paris, Fr 37

Fabris M, Abbriano RM, Pernice M et al (2020) Emerging technologies in algal biotechnology: toward the establishment of a sustainable, algae-based bioeconomy. Front Plant Sci 11:279

Ferreira GF, Ríos Pinto LF, Filho RM, Fregolente LV (2019) A review on lipid production from microalgae: association between cultivation using waste streams and fatty acid profiles. Renew Sustain Energy Rev 109:448-466

García-González M, Moreno J, Manzano JC, Florencio FJ, Guerrero MG (2005) Production of Dunaliella salina biomass rich in 9 -cis- $\beta$-carotene and lutein in a closed tubular photobioreactor. J Biotechnol 115(1):81-90

García-Malea MC, Acién FG, Del Río E, Fernández JM et al (2009) Production of astaxanthin by Haematococcus pluvialis: taking the one-step system outdoors. Biotechnol Bioeng 102(2):651-657

Ge S, Qiu S, Tremblay D, Viner K, Champagne P, Jessop PG (2018) Centrate wastewater treatment with Chlorella vulgaris: simultaneous enhancement of nutrient removal, biomass and lipid production. Chem Eng J 342:310-320

Gifuni I, Pollio A, Safi C et al (2019) Current bottlenecks and challenges of the microalgal biorefinery. Trends Biotechnol 37:242-252

Gomma AE, Lee S-K, Sun SM et al (2015) Improvement in oil production by increasing malonyl-CoA and glycerol-3phosphate pools in Scenedesmus quadricauda. Indian $\mathrm{J}$ Microbiol 55:447-455

Guiry MD (2012) How many species of algae are there? J Phycol 48:1057-1063

Guldhe A, Renuka N, Singh P, Bux F (2019) Effect of phytohormones from different classes on gene expression of Chlorella sorokiniana under nitrogen limitation for enhanced biomass and lipid production. Algal Res 40:101518

Halim R, Danquah MK, Webley PA (2012) Extraction of oil from microalgae for biodiesel production: a review. Biotechnol Adv 30:709-732 
Hang LT, Mori K, Tanaka Y, Morikawa M, Toyama T (2020) Enhanced lipid productivity of Chlamydomonas reinhardtii with combination of $\mathrm{NaCl}$ and $\mathrm{CaCl}_{2}$ stresses. Bioprocess Biosyst Eng 43(6):971-980

Hariskos I, Posten C (2014) Biorefinery of microalgae-opportunities and constraints for different production scenarios. Biotechnol J 9:739-752

Hidalgo P, Ciudad G, Navia R (2016) Evaluation of different solvent mixtures in esterifiable lipids extraction from microalgae Botryococcus braunii for biodiesel production. Bioresour Technol. https://doi.org/10.1016/j.biortech. 2015.11.031

Hingsamer M, Jungmeier G (2019) Biorefineries. In: The role of bioenergy in the bioeconomy. Elsevier, pp 179-222

Ho SH, Chen YD, Chang CY et al (2017) Feasibility of $\mathrm{CO}_{2}$ mitigation and carbohydrate production by microalga Scenedesmus obliquus CNW-N used for bioethanol fermentation under outdoor conditions: effects of seasonal changes. Biotechnol Biofuels 10(1):1-13

Hossain Z, Johnson NE, Wang L, Blackshaw RE, Gan Y (2019) Comparative analysis of oil and protein content and seed yield of five Brassicaceae oilseeds on the Canadian prairie. Ind Crops Prod 136:77-86

Hu Q, Sommerfeld M, Jarvis E et al (2008) Microalgal triacylglycerols as feedstocks for biofuel production: perspectives and advances. Plant J 54:621-639

Huang WC, Kim JD (2016) Nickel oxide nanoparticle-based method for simultaneous harvesting and disruption of microalgal cells. Bioresour Technol 218:1290-1293

IEA IEA (2017) Energy technology essentials: fuel cells. Int Energy Agency

Ip PF, Chen F (2005) Production of astaxanthin by the green microalga Chlorella zofingiensis in the dark. Process Biochem 40(2):733-738

Islam MA, Magnusson M, Brown RJ et al (2013) Microalgal species selection for biodiesel production based on fuel properties derived from fatty acid profiles. Energies. https://doi.org/10.3390/en6115676

Janssen JH, Wijffels RH, Barbosa MJ (2019) Lipid production in Nannochloropsis gaditana during nitrogen starvation. Biology (basel) 8:5

Joun J, Hong ME, Sirohi R, Sim SJ (2021) Enhanced biomass production through a repeated sequential auto-and heterotrophic culture mode in Chlorella protothecoides. Bioresour Technol 338:125532

Judge MP, Harel O, Lammi-Keefe CJ (2007) Maternal consumption of a docosahexaenoic acid-containing functional food during pregnancy: benefit for infant performance on problem-solving but not on recognition memory tasks at age 9 mo. Am J Clin Nutr 85:1572-1577

Kannaujiya VK, Singh PR, Kumar D, Sinha RP (2020) Phycobiliproteins in microalgae: occurrence, distribution, and biosynthesis. In: Pigments from microalgae handbook. Springer, pp 43-68

Khoo KS, Chew KW, Yew GY et al (2020) Recent advances in downstream processing of microalgae lipid recovery for biofuel production. Bioresour Technol 304:122996

Kim HS, Devarenne TP, Han A (2018) Microfluidic systems for microalgal biotechnology: a review. Algal Res 30:149-161
Kiran BR, Venkata Mohan S (2021) Microalgal cell biofactory-therapeutic, nutraceutical and functional food applications. Plants 10:836

Kleinegris DM, Janssen M, Brandenburg WA, Wijffels RH (2011) Continuous production of carotenoids from $\mathrm{Du}$ naliella salina. Enzyme Microb Technol 48(3):253-259

Köhler P, Nehrbass-Ahles C, Schmitt J et al (2017) A 156 kyr smoothed history of the atmospheric greenhouse gases $\mathrm{CO}_{2}, \mathrm{CH}_{4}$, and $\mathrm{N}_{2} \mathrm{O}$ and their radiative forcing. Earth Syst Sci Data 9:363-387

Koutra E, Tsafrakidou P, Sakarika M, Kornaros M (2020) Microalgal biorefinery. In: Microalgae cultivation for biofuels production. Elsevier, pp 163-185

Kumar S, Tiwari P, Zymbler M (2019) Internet of Things is a revolutionary approach for future technology enhancement: a review. J Big Data 6:1-21

Lafarga T, Sánchez-Zurano A, Morillas-España A, Acién-Fernández FG (2021) Extremophile microalgae as feedstock for high-value carotenoids: A review. Int $\mathrm{J}$ Food Sci Technol

Lakshmikandan M, Murugesan AG, Wang S, Abomohra AEF, Jovita PA, Kiruthiga S (2020) Sustainable biomass production under $\mathrm{CO}_{2}$ conditions and effective wet microalgae lipid extraction for biodiesel production. J Clean Prod 247:119398

Lam MK, Tan IS, Lee KT (2014) Utilizing lipid-extracted microalgae biomass residues for maltodextrin production. Chem Eng J. https://doi.org/10.1016/j.cej.2013.09.023

Lauritano C, Andersen JH, Hansen E et al (2016) Bioactivity screening of microalgae for antioxidant, anti-inflammatory, anticancer, anti-diabetes, and antibacterial activities. Front Mar Sci 3:68

Lee I, Han JI (2015) Simultaneous treatment (cell disruption and lipid extraction) of wet microalgae using hydrodynamic cavitation for enhancing the lipid yield. Bioresour Technol 186(246):251

Lee P, Schmidt-Dannert C (2002) Metabolic engineering towards biotechnological production of carotenoids in microorganisms. Appl Microbiol Biotechnol 60:1-11

Lee S, Oh Y, Kim D et al (2011) Converting carbohydrates extracted from marine algae into ethanol using various ethanolic Escherichia coli strains. Appl Biochem Biotechnol. https://doi.org/10.1007/s12010-011-9181-7

Lee SY, Khoiroh I, Vo D-VN et al (2020) Techniques of lipid extraction from microalgae for biofuel production: a review. Environ Chem Lett 19:231-251

Li Y, Ghasemi Naghdi F, Garg S et al (2014) A comparative study: the impact of different lipid extraction methods on current microalgal lipid research. Microb Cell Fact. https:// doi.org/10.1186/1475-2859-13-14

Li Z, Meng T, Ling X et al (2018) Overexpression of malonylCoA: ACP transacylase in Schizochytrium sp. to improve polyunsaturated fatty acid production. J Agric Food Chem 66:5382-5391

Li F, Cai M, Lin M et al (2020) Enhanced biomass and astaxanthin production of Haematococcus pluvialis by a cell transformation strategy with optimized initial biomass density. Mar Drugs 18:341

Liang Y, Beardall J, Heraud P (2006) Effects of nitrogen source and UV radiation on the growth, chlorophyll fluorescence and fatty acid composition of Phaeodactylum tricornutum 
and Chaetoceros muelleri (Bacillariophyceae). J Photochem Photobiol B Biol 82:161-172

Liu J, Yuan C, Hu G, Li F (2012) Effects of light intensity on the growth and lipid accumulation of microalga Scenedesmus sp. 11-1 under nitrogen limitation. Appl Biochem Biotechnol 166:2127-2137

Liu B, Liu J, Sun P et al (2015) Sesamol enhances cell growth and the biosynthesis and accumulation of docosahexaenoic acid in the microalga Crypthecodinium cohnii. J Agric Food Chem 63:5640-5645

Liu H, Zhang L, Mei L, Quampah A, He Q, Zhang B et al (2020) qOil-3, a major QTL identification for oil content in cottonseed across genomes and its candidate gene analysis. Ind Crops Prod 145:112070

Luengo E, Martínez JM, Bordetas A, Álvarez I, Raso J (2015) Influence of the treatment medium temperature on lutein extraction assisted by pulsed electric fields from Chlorella vulgaris. Innov Food Sci Emerg Technol 29:15-22

Ma X, Zheng H, Addy M, Anderson E, Liu Y, Chen P, Ruan R (2016) Cultivation of Chlorella vulgaris in wastewater with waste glycerol: strategies for improving nutrients removal and enhancing lipid production. Bioresour Technol 207:252-261

Ma R, Zhang Z, Ho S-H et al (2020) Two-stage bioprocess for hyper-production of lutein from microalga Chlorella sorokiniana FZU60: effects of temperature, light intensity, and operation strategies. Algal Res 52:102119

Markou G, Angelidaki I, Georgakakis D (2012) Microalgal carbohydrates: An overview of the factors influencing carbohydrates production, and of main bioconversion technologies for production of biofuels. Appl Microbiol Biotechnol 96:631-645

Martins F, Felgueiras C, Smitkova M, Caetano N (2019) Analysis of fossil fuel energy consumption and environmental impacts in European countries. Energies 12:964

Mayers JJ, Vaiciulyte S, Malmhäll-Bah E et al (2018) Identifying a marine microalgae with high carbohydrate productivities under stress and potential for efficient flocculation. Algal Res 31:430-442

Mazzucchi L, Xu Y, Harvey P (2020) Stereoisomers of colourless carotenoids from the marine microalga $\mathrm{Du}$ naliella salina. Molecules 25:1880

Mehta P, McAuley DF, Brown M et al (2020) COVID-19: consider cytokine storm syndromes and immunosuppression. Lancet 395:1033-1034

Menegazzo LM, Fonseca GG (2019) Biomass recovery and lipid extraction processes for microalgae biofuels production: a review. Renew Sustain Energy Rev 107:87-107

Minyuk G, Sidorov R, Solovchenko A (2020) Effect of nitrogen source on the growth, lipid, and valuable carotenoid production in the green microalga Chromochloris zofingiensis. J Appl Phycol 32:923-935

Mirizadeh S, Nosrati M, Shojaosadati SA (2020) Synergistic effect of nutrient and salt stress on lipid productivity of Chlorella vulgaris through two-stage cultivation. BioEnergy Res 13(2):507-517

Moheimani NR, Borowitzka MA (2011) Increased $\mathrm{CO}_{2}$ and the effect of $\mathrm{pH}$ on growth and calcification of Pleurochrysis carterae and Emiliania huxleyi (Haptophyta) in semicontinuous cultures. Appl Microbiol Biotechnol 90:1399-1407
Molino A, Mehariya S, Iovine A et al (2018) Extraction of astaxanthin and lutein from microalga Haematococcus pluvialis in the red phase using $\mathrm{CO}_{2}$ supercritical fluid extraction technology with ethanol as co-solvent. Mar Drugs 16:432

Molino A, Mehariya S, Iovine A et al (2020) Enhancing biomass and lutein production from Scenedesmus almeriensis: effect of carbon dioxide concentration and culture medium reuse. Front Plant Sci 11:415

Mondal M, Khanra S, Tiwari ON, Gayen K, Halder GN (2016) Role of carbonic anhydrase on the way to biological carbon capture through microalgae - a mini review. Environ Prog Sustain Energy 35(6):1605-1615

Mtaki K, Kyewalyanga MS, Mtolera MSP (2020) Assessment of antioxidant contents and free radical-scavenging capacity of Chlorella vulgaris cultivated in low cost media. Appl Sci 10:8611

Mulchandani K, Kar JR, Singhal RS (2015) Extraction of lipids from Chlorella saccharophila using high-pressure homogenization followed by three phase partitioning. Appl Biochem Biotechnol 176(6):1613-1626

Muylaert K, Bastiaens L, Vandamme D, Gouveia L (2017) Harvesting of microalgae: Overview of process options and their strengths and drawbacks. Microalgae-Based Biofuels Bioprod 113-132

Nadzir SM, Yusof N, Nordin N et al (2018) Combination effect of temperature and light intensity on lipid productivity of Tetradesmus obliquus. J Phys Conf Ser 1097:12038

Nagappan S, Devendran S, Tsai PC, Dahms HU, Ponnusamy VK (2019) Potential of two-stage cultivation in microalgae biofuel production. Fuel 252:339-349

Nascimento IA, Marques SSI, Cabanelas ITD et al (2013) Screening microalgae strains for biodiesel production: lipid productivity and estimation of fuel quality based on fatty acids profiles as selective criteria. Bioenergy Res 6:1-13. https://doi.org/10.1007/s12155-012-9222-2

Nguyen THT, Park S, Jeong J, Shin YS, Sim SJ, Jin E (2020) Enhancing lipid productivity by modulating lipid catabolism using the CRISPR-Cas9 system in Chlamydomonas. J Appl Phycol 32(5):2829-2840

Niccolai A, Zittelli GC, Rodolfi L et al (2019) Microalgae of interest as food source: Biochemical composition and digestibility. Algal Res 42:101617

Novoveská L, Ross ME, Stanley MS et al (2019) Microalgal carotenoids: a review of production, current markets, regulations, and future direction. Mar Drugs 17:640

Oliver L, Dietrich T, Marañón I et al (2020) Producing omega-3 polyunsaturated fatty acids: a review of sustainable sources and future trends for the EPA and DHA market. Resources 9:148

Ong HC, Mahlia TMI, Masjuki HH, Norhasyima RS (2011) Comparison of palm oil, Jatropha curcas and Calophyllum inophyllum for biodiesel: a review. Renew Sustain Energy Rev 15:3501-3515

Onumaegbu C, Mooney J, Alaswad A, Olabi AG (2018) Pretreatment methods for production of biofuel from microalgae biomass. Renew Sust Energ Rev 93:16-26

Orejuela-Escobar L, Gualle A, Ochoa-Herrera V, Philippidis GP (2021) Prospects of microalgae for biomaterial production and environmental applications at biorefineries. Sustainability 13(6):3063 
Oslan SNH, Shoparwe NF, Yusoff AH et al (2021) A Review on Haematococcus pluvialis bioprocess optimization of green and red stage culture conditions for the production of natural astaxanthin. Biomolecules 11:256

Pal D, Khozin-Goldberg I, Cohen Z, Boussiba S (2011) The effect of light, salinity, and nitrogen availability on lipid production by Nannochloropsis sp. Appl Microbiol Biotechnol 90:1429-1441

Park JY, Nam B, Choi SA, Oh YK, Lee JS (2014) Effects of anionic surfactant on extraction of free fatty acid from Chlorella vulgaris. Bioresour Technol 166:620-624

Park H, Jung D, Lee J, Kim P et al (2018) Improvement of biomass and fatty acid productivity in ocean cultivation of Tetraselmis sp. using hypersaline medium. J Appl Phycol 30(5):2725-2735

Patel A, Mikes F, Matsakas L (2018) An overview of current pretreatment methods used to improve lipid extraction from oleaginous microorganisms. Molecules 23:1562

Piligaev AV, Sorokina KN, Samoylova YV, Parmon VN (2019) Production of microalgal biomass with high lipid content and their catalytic processing into biodiesel: a review. Catal Ind 11:349-359

Poh ZL, Kadir WNA, Lam MK, Uemura Y et al (2020) The effect of stress environment towards lipid accumulation in microalgae after harvesting. Renew Energy 154:1083-1091

Rai MP, Gautom T, Sharma N (2015) Effect of salinity, pH, light intensity on growth and lipid production of microalgae for bioenergy application. Online J Biol Sci 15:260

Raposo MFDJ, De Morais AMMB, De Morais RMSC (2015) Carotenoids from marine microalgae: a valuable natural source for the prevention of chronic diseases. Mar Drugs 13:5128-5155

Rathod JP, Vira C, Lali AM, Prakash G (2020) Metabolic engineering of Chlamydomonas reinhardtii for enhanced $\beta$-carotene and lutein production. Appl Biochem Biotechnol 190:1457-1469

Ratomski P, Hawrot-Paw M (2021) Influence of nutrient-stress conditions on Chlorella vulgaris biomass production and lipid content. Catalysts 11:573

Rebelo BA, Farrona S, Ventura MR, Abranches R (2020) Canthaxanthin, a red-hot carotenoid: applications, synthesis, and biosynthetic evolution. Plants 9:1039

Ren LJ, Ji XJ, Huang H et al (2010) Development of a stepwise aeration control strategy for efficient docosahexaenoic acid production by Schizochytrium sp. Appl Microbiol Biotechnol. https://doi.org/10.1007/s00253-010-2639-7

Rengel R, Smith RT, Haslam RP et al (2018) Overexpression of acetyl-CoA synthetase (ACS) enhances the biosynthesis of neutral lipids and starch in the green microalga Chlamydomonas reinhardtii. Algal Res 31:183-193

Rizza LS, Smachetti MES, Do Nascimento M et al (2017) Bioprospecting for native microalgae as an alternative source of sugars for the production of bioethanol. Algal Res 22:140-147

Rosa SM, Soria MA, Vélez CG, Galvagno MA (2010) Improvement of a two-stage fermentation process for docosahexaenoic acid production by Aurantiochytrium limacinum SR21 applying statistical experimental designs and data analysis. Bioresour Technol. https://doi.org/10. 1016/j.biortech.2009.11.056
Ryckebosch E, Bruneel C, Termote-Verhalle R et al (2014) Nutritional evaluation of microalgae oils rich in omega-3 long chain polyunsaturated fatty acids as an alternative for fish oil. Food Chem. https://doi.org/10.1016/j.foodchem. 2014.03.087

Sajjadi B, Chen W, Abdul RAA, Ibrahim S (2018) Microalgae lipid and biomass for biofuel production: a comprehensive review on lipid enhancement strategies and their effects on fatty acid composition. Renew Sustain Energy Rev 97:200-232

Sánchez JF, Fernández-Sevilla JM, Acién FG, Cerón MC, Pérez-Parra J, Molina-Grima E (2008) Biomass and lutein productivity of Scenedesmus almeriensis: influence of irradiance, dilution rate and temperature. Appl Microbiol Biotechnol 79(5):719-729

Sathasivam R, Radhakrishnan R, Hashem A, Abd Allah EF (2019) Microalgae metabolites: a rich source for food and medicine. Saudi J Biol Sci 26:709-722

Sati H, Mitra M, Mishra S, Baredar P (2019) Microalgal lipid extraction strategies for biodiesel production: a review. Algal Res 38:101413

Sed G, Cicci A, Jessop PG, Bravi M (2018) A novel switchablehydrophilicity, natural deep eutectic solvent (NaDES)based system for bio-safe biorefinery. RSC Adv 8(65):37092-37097

Seo SH, Ha JS, Yoo C et al (2017) Light intensity as major factor to maximize biomass and lipid productivity of Ettlia sp. in $\mathrm{CO}_{2}$-controlled photoautotrophic chemostat. Bioresour Technol 244:621-628

Sharma PK, Saharia M, Srivstava R, Kumar S, Sahoo L (2018) Tailoring microalgae for efficient biofuel production. Front Mar Sci 5:382

Shekh AY, Shrivastava P, Gupta A et al (2016) Biomass and lipid enhancement in Chlorella sp. with emphasis on biodiesel quality assessment through detailed FAME signature. Bioresour Technol. https://doi.org/10.1016/j.biortech. 2015.11.058

Shene C, Monsalve MT, Vergara D, Lienqueo ME, Rubilar M (2016) High pressure homogenization of Nannochloropsis oculata for the extraction of intracellular components: effect of process conditions and culture age. Eur J Lipid Sci Technol 118:631-639

Shin YS, Choi HI, Choi JW, Lee JS, Sung YJ, Sim SJ (2018) Multilateral approach on enhancing economic viability of lipid production from microalgae: a review. Bioresour Technol 258:335-344

Shokravi Z, Shokravi H, Chyuan OH, Lau WJ, Koloor SSR, Petru M, Ismail AF (2020) Improving lipid productivity in microalgae by bilateral enhancement of biomass and lipid contents: a review. Sustainability 12(21):9083

Sibi G, Shetty V, Mokashi K (2016) Enhanced lipid productivity approaches in microalgae as an alternate for fossil fuels-a review. J Energy Inst 89:330-334

Sirohi R, Tarafdar A, Singh S, et al (2020) Green processing and biotechnological potential of grape pomace: current trends and opportunities for sustainable biorefinery. Bioresour Technol 123771

Sirohi R, Joun J, Choi HII et al (2021a) Algal glycobiotechnology: omics approaches for strain improvement. Microb Cell Fact 20:1-10 
Sirohi R, Lee JS, Yu BS et al (2021b) Sustainable production of polyhydroxybutyrate from autotrophs using $\mathrm{CO}_{2}$ as feedstock: challenges and opportunities. Bioresour Technol 341:125751

Soto-Sierra L, Stoykova P, Nikolov ZL (2018) Extraction and fractionation of microalgae-based protein products. Algal Res 36:175-192

Sreekumar N, Giri Nandagopal MS, Vasudevan A et al (2016) Marine microalgal culturing in open pond systems for biodiesel production - critical parameters. J Renew Sustain Energy 8:023105. https://doi.org/10.1063/1.4945574

Sreekumar N, Chennattussery AJ, Mariya A, Selvaraju N (2018) Anaerobic digester sludge as nutrient source for culturing of microalgae for economic biodiesel production. Int $\mathrm{J}$ Environ Sci Technol 15:2607-2614

Sulochana SB, Arumugam M (2020) Targeted metabolomic and biochemical changes during nitrogen stress mediated lipid accumulation in Scenedesmus quadricauda CASA CC202. Front Bioeng Biotechnol 8:1223

Sumiya N, Kawase Y, Hayakawa J et al (2015) Expression of cyanobacterial acyl-ACP reductase elevates the triacylglycerol level in the red alga Cyanidioschyzon merolae. Plant Cell Physiol 56:1962-1980

Sun Z, Li T, Zhou Z, Jiang Y (2015) Microalgae as a source of lutein: chemistry, biosynthesis, and carotenogenesis. Microalgae Biotechnol 37-58

Sun D, Zhang Z, Chen F (2018) Effects of light intensity, light quality, and illumination period on cell growth, TFA accumulation, and DHA production in Crypthecodinium sp. SUN. J Appl Phycol 30:1495-1502

Tamagno S, Aznar-Moreno AJ, Durrett PT, Prasad PVV, Rotundo JL, Ciampitti IO (2020) Dynamics of oil and fatty acid accumulation during seed development in historical soybean varieties. Field Crops Res 248:107719

Tan KWM, Lee YK (2017) Expression of the heterologous Dunaliella tertiolecta fatty acyl-ACP thioesterase leads to increased lipid production in Chlamydomonas reinhardtii. J Biotechnol 247:60-67

Torres S, Acien G, García-Cuadra F, Navia R (2017) Direct transesterification of microalgae biomass and biodiesel refining with vacuum distillation. Algal Res 28:30-38

Trivedi J, Aila M, Bangwal DP et al (2015) Algae based biorefinery-how to make sense? Renew Sustain Energy Rev 47:295-307

Udayan A, Arumugam M, Pandey A (2017) Nutraceuticals from algae and cyanobacteria. In: Algal green chemistry. Elsevier, pp 65-89

Udayan A, Kathiresan S, Arumugam M (2018) Kinetin and Gibberellic acid (GA3) act synergistically to produce high value polyunsaturated fatty acids in Nannochloropsis oceanica CASA CC201. Algal Res 32:182-192

Udayan A, Sabapathy H, Arumugam M (2020) Stress hormones mediated lipid accumulation and modulation of specific fatty acids in Nannochloropsis oceanica CASA CC201. Bioresour Technol 310:123437. https://doi.org/10.1016/j. biortech.2020.123437

Udayan A, Pandey AK, Sharma P, et al (2021) Emerging industrial applications of microalgae: challenges and future perspectives. Syst Microbiol Biomanufact 1-21

Ursu AV, Marcati A, Sayd T et al (2014) Extraction, fractionation and functional properties of proteins from the microalgae Chlorella vulgaris. Bioresour Technol. https:// doi.org/10.1016/j.biortech.2014.01.071

Uyaguari-Diaz MI, Chan M, Chaban BL et al (2016) A comprehensive method for amplicon-based and metagenomic characterization of viruses, bacteria, and eukaryotes in freshwater samples. Microbiome 4:1-19

Viegas CV, Hachemi I, Mäki-Arvela P et al (2015) Algal products beyond lipids: Comprehensive characterization of different products in direct saponification of green alga Chlorella sp. Algal Res. https://doi.org/10.1016/j.algal. 2015.06.014

Wahidin S, Idris A, Yusof NM, Kamis NHH, Shaleh SRM (2018) Optimization of the ionic liquid-microwave assisted one-step biodiesel production process from wet microalgal biomass. Energy Convers Manag 171:1397-1404

Wan DH, Zheng B-Y, Ke M-R et al (2017) C-Phycocyanin as a tumour-associated macrophage-targeted photosensitiser and a vehicle of phthalocyanine for enhanced photodynamic therapy. Chem Commun 53:4112-4115

Wang ML, Raymer P, Chinnan M, Pittman RN (2012) Screening of the USDA peanut germplasm for oil content and fatty acid composition. Biomass Bioenergy 39:336-343

Wang SK, Hu YR, Wang F et al (2014) Scale-up cultivation of Chlorella ellipsoidea from indoor to outdoor in bubble column bioreactors. Bioresour Technol. https://doi.org/10. 1016/j.biortech.2014.01.023

Wang XW, Huang L, Ji PY, Chen CP, Li XS, Gao YH, Liang JR (2019) Using a mixture of wastewater and seawater as the growth medium for wastewater treatment and lipid production by the marine diatom Phaeodactylum tricornutum. Bioresour Technol 289:121681

Wei D, Chen F, Chen G, Zhang X, Liu L, Zhang H (2008) Enhanced production of lutein in heterotrophic Chlorella protothecoides by oxidative stress. Sci China Ser C Life Sci 51(12):1088-1093

Weill P, Plissonneau C, Legrand P et al (2020) May omega-3 fatty acid dietary supplementation help reduce severe complications in Covid-19 patients? Biochimie 179:275-280

Wells ML, Potin P, Craigie JS et al (2017) Algae as nutritional and functional food sources: revisiting our understanding. J Appl Phycol 29:949-982

Whitmore A, Agarwal A, Da Xu L (2014) The Internet of Things-a survey of topics and trends. Inf Syst Front 17:261-274. https://doi.org/10.1007/S10796-014-9489-2

Wu Q, Liu L, Miron A et al (2016) The antioxidant, immunomodulatory, and anti-inflammatory activities of Spirulina: an overview. Arch Toxicol 90:1817-1840

Xia L, Ge H, Zhou X, Zhang D, Hu C (2013) Photoautotrophic outdoor two-stage cultivation for oleaginous microalgae Scenedesmus obtusus XJ-15. Bioresour Technol 144:261-267

Yang L, Chen J, Qin S et al (2018) Growth and lipid accumulation by different nutrients in the microalga Chlamydomonas reinhardtii. Biotechnol Biofuels 11:40

Yoo C, Jun SY, Lee JY, Ahn CY, Oh HM (2010) Selection of microalgae for lipid production under high levels carbon dioxide. Bioresour Technol 101(1):S71-S74

Yoo G, Park WK, Kim CW, Choi YE, Yang JW (2012) Direct lipid extraction from wet Chlamydomonas reinhardtii 
biomass using osmotic shock. Bioresour Technol 123:717-722

Yoo G, Park MS, Yang JW, Choi M (2015) Lipid content in microalgae determines the quality of biocrude and energy return on investment of hydrothermal liquefaction. Appl Energy 156:354-361

Yun JH, Cho DH, Lee S, Heo J, Tran QG, Chang YK, Kim HS (2018) Hybrid operation of photobioreactor and wastewater-fed open raceway ponds enhances the dominance of target algal species and algal biomass production. Algal Res 29:319-329

Zhang S, He Y, Sen B et al (2018) Alleviation of reactive oxygen species enhances PUFA accumulation in
Schizochytrium sp. through regulating genes involved in lipid metabolism. Metab Eng Commun 6:39-48

Zhao B, Su Y (2014) Process effect of microalgal-carbon dioxide fixation and biomass production: a review. Renew Sustain Energy Rev 31:121-132

Zhu LD, Li ZH, Hiltunen E (2016) Strategies for lipid production improvement in microalgae as a biodiesel feedstock. Biomed Res Int 2016

Publisher's Note Springer Nature remains neutral with regard to jurisdictional claims in published maps and institutional affiliations. 